\title{
LEVEL II SCOUR ANALYSIS FOR BRIDGE 32 (SHERTH00470032) on TOWN HIGHWAY 47, crossing ROARING BROOK, SHERBURNE, VERMONT
}

Open-File Report 98-258

Prepared in cooperation with

VERMONT AGENCY OF TRANSPORTATION

and

FEDERAL HIGHWAY ADMINISTRATION

U.S. Department of the Interior

U.S. Geological Survey

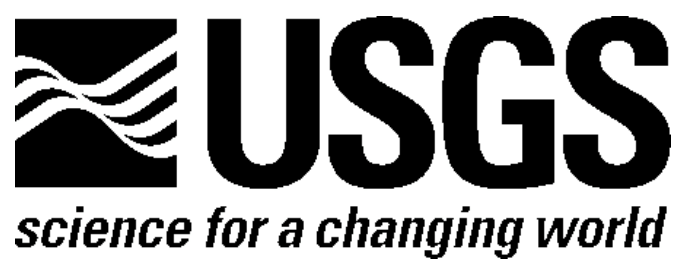


LEVEL II SCOUR ANALYSIS FOR

BRIDGE 32 (SHERTH00470032) on

TOWN HIGHWAY 47, crossing

ROARING BROOK,

SHERBURNE, VERMONT

By MICHAEL A. IVANOFF AND TIMOTHY SEVERANCE

U.S. Geological Survey

Open-File Report 98-258

Prepared in cooperation with

VERMONT AGENCY OF TRANSPORTATION

and

FEDERAL HIGHWAY ADMINISTRATION 


\title{
U.S. DEPARTMENT OF THE INTERIOR BRUCE BABBITT, Secretary
}

\author{
U.S. GEOLOGICAL SURVEY
}

Thomas J. Casadevall, Acting Director

For additional information write to:

District Chief

U.S. Geological Survey 361 Commerce Way

Pembroke, NH 03275-3718
Copies of this report may be purchased from:

U.S. Geological Survey

Branch of Information Services

Open-File Reports Unit

Box 25286

Denver, CO 80225-0286 


\section{CONTENTS}

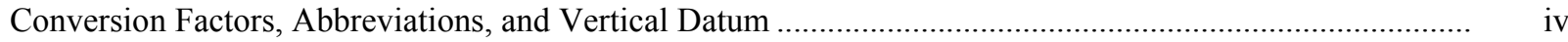

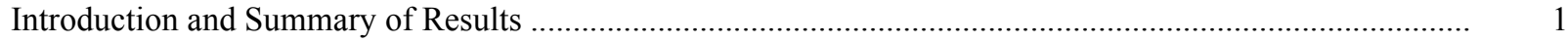

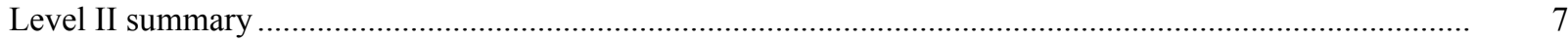

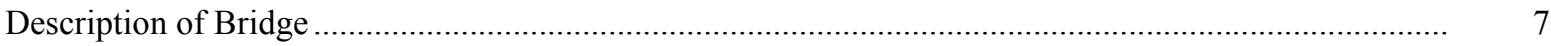

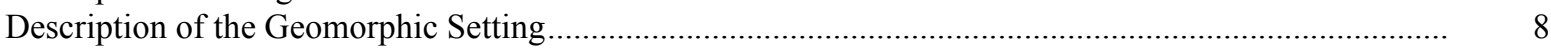

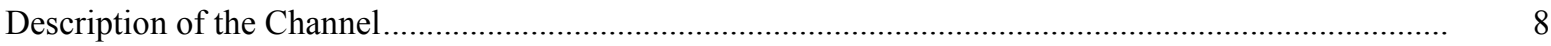

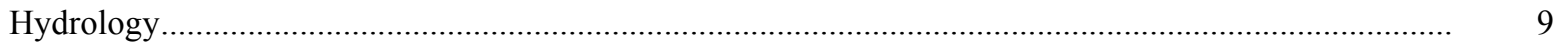

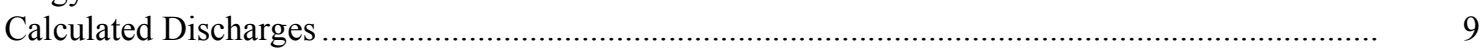

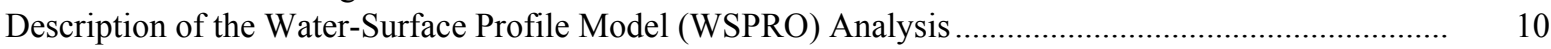

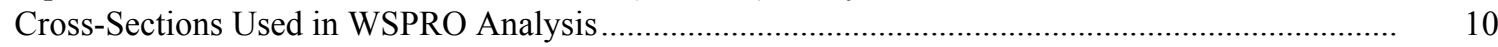

Data and Assumptions Used in WSPRO Model ........................................................................ 11

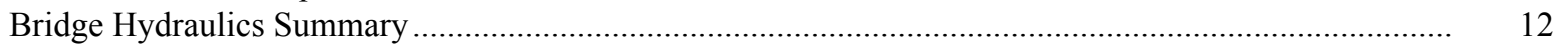

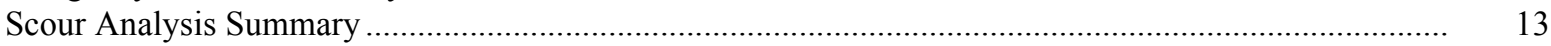

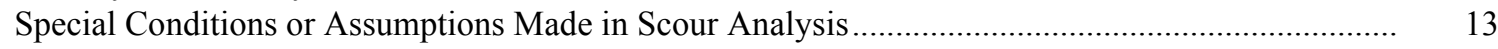

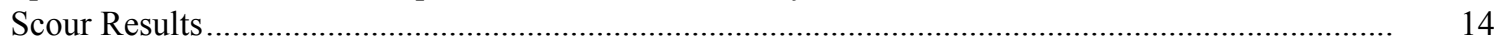

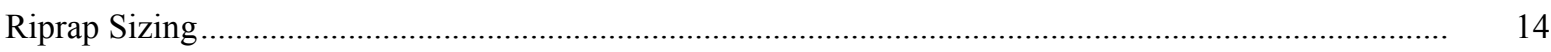

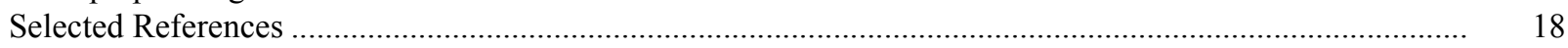

Appendices:

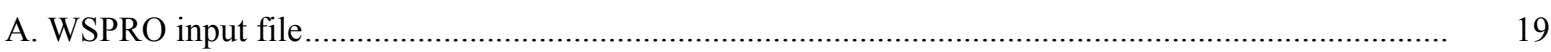

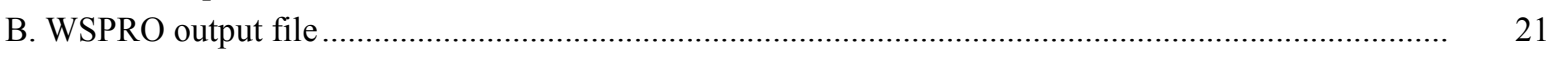

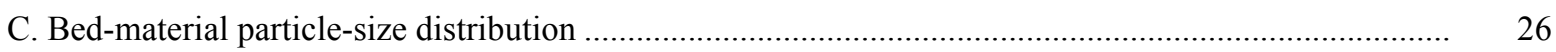

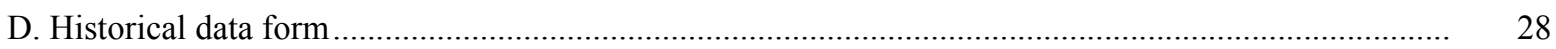

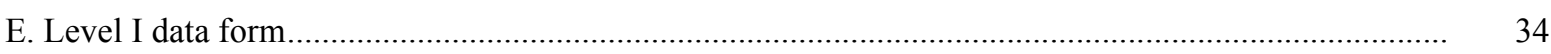

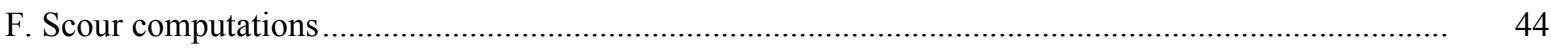

\section{FIGURES}

1. Map showing location of study area on USGS 1:24,000 scale map

2. Map showing location of study area on Vermont Agency of Transportation town highway map

3. Structure SHERTH00470032 viewed from upstream (October 2, 1995)

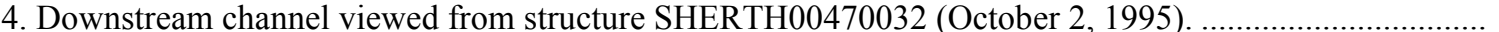

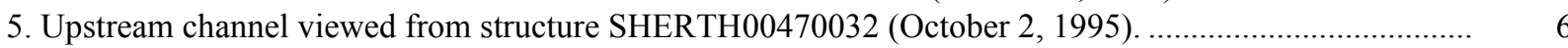

6. Structure SHERTH00470032 viewed from downstream (October 2, 1995).

7. Water-surface profiles for the 100- and 500-year discharges at structure SHERTH00470032 on Town Highway 47, crossing Roaring Brook, Sherburne, Vermont.

8. Scour elevations for the 100- and 500-year discharges at structure

SHERTH00470032 on Town Highway 47, crossing Roaring Brook,

Sherburne, Vermont.

\section{TABLES}

1. Remaining footing/pile depth at abutments for the 100-year discharge at structure

SHERTH00470032 on Town Highway 47, crossing Roaring Brook,

Sherburne, Vermont

2. Remaining footing/pile depth at abutments for the 500-year discharge at structure

SHERTH00470032 on Town Highway 47, crossing Roaring Brook,

Sherburne, Vermont 


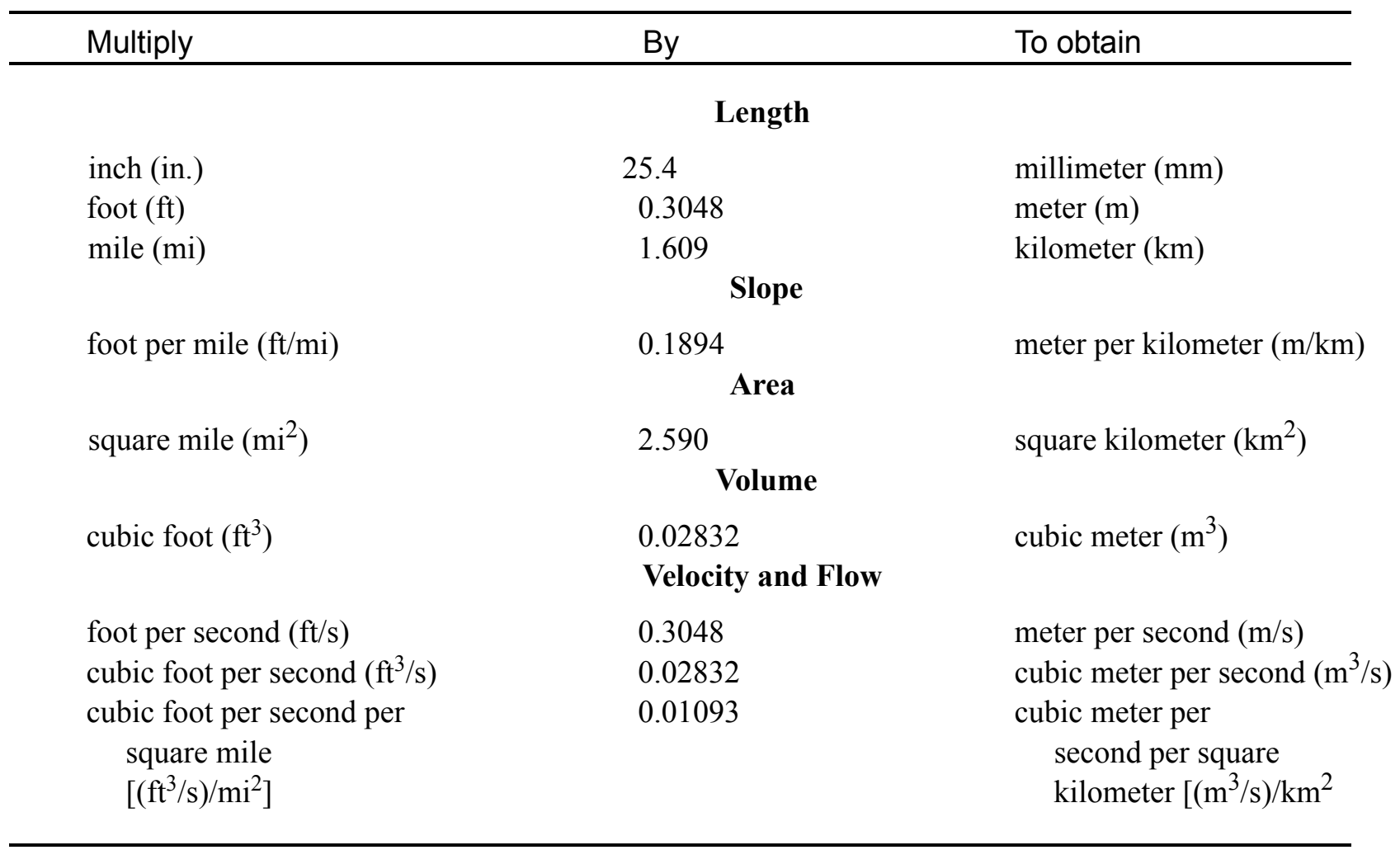

\section{OTHER ABBREVIATIONS}

$\begin{array}{lrlr}\mathrm{BF} & \text { bank full } & \text { LWW } & \text { left wingwall } \\ \mathrm{cfs} & \text { cubic feet per second } & \text { Max } & \text { maximum } \\ \mathrm{D}_{50} & \text { median diameter of bed material } & \text { MC } & \text { main channel } \\ \mathrm{DS} & \text { downstream } & \text { RAB } & \text { right abutment } \\ \mathrm{elev} & \text { elevation } & \text { RABUT } & \text { face of right abutment } \\ \mathrm{f} / \mathrm{p} & \text { flood plain } & \text { RB } & \text { right bank } \\ \mathrm{ft} & \text { square feet } & \text { ROB } & \text { right overbank } \\ \mathrm{ft} / \mathrm{ft} & \text { feet per foot } & \text { RWW } & \text { right wingwall } \\ \mathrm{FEMA} & \text { Federal Emergency Management Agency } & \text { TH } & \text { town highway } \\ \mathrm{FHWA} & \text { Federal Highway Administration } & \text { UB } & \text { under bridge } \\ \mathrm{JCT} & \text { junction } & \text { US } & \text { upstream } \\ \text { LAB } & \text { left abutment } & \text { USGS } & \text { United States Geological Survey } \\ \text { LABUT } & \text { face of left abutment } & \text { VTAOT } & \text { Vermont Agency of Transportation } \\ \text { LB } & \text { left bank } & \text { WSPRO } & \text { water-surface profile model } \\ \text { LOB } & \text { left overbank } & \text { yr } & \text { year }\end{array}$

In this report, the words "right" and "left" refer to directions that would be reported by an observer facing downstream. Sea level: In this report, "sea level" refers to the National Geodetic Vertical Datum of 1929-- a geodetic datum derived from a general adjustment of the first-order level nets of the United States and Canada, formerly called Sea Level Datum of 1929.

In the appendices, the above abbreviations may be combined. For example, USLB would represent upstream left bank. 


\title{
LEVEL II SCOUR ANALYSIS FOR BRIDGE 32 (SHERTH00470032) ON TOWN HIGHWAY 47, CROSSING ROARING BROOK, SHERBURNE, VERMONT
}

\author{
By Michael A. Ivanoff and Timothy Severance
}

\section{INTRODUCTION AND SUMMARY OF RESULTS}

This report provides the results of a detailed Level II analysis of scour potential at structure SHERTH00470032 on Town Highway 47 crossing Roaring Brook, Sherburne, Vermont (figures 1-8). A Level II study is a basic engineering analysis of the site, including a quantitative analysis of stream stability and scour (FHWA, 1993). Results of a Level I scour investigation also are included in appendix $\mathrm{E}$ of this report. A Level I investigation provides a qualitative geomorphic characterization of the study site. Information on the bridge, gleaned from Vermont Agency of Transportation (VTAOT) files, was compiled prior to conducting Level I and Level II analyses and is found in appendix D.

The site is in the Green Mountain section of the New England physiographic province in central Vermont. The $5.55-\mathrm{mi}^{2}$ drainage area is in a predominantly rural and forested basin. In the vicinity of the study site, the surface cover consists of cut grass and a few houses upstream of the bridge with trees on the immediate banks. Downstream of the bridge is forested.

In the study area, Roaring Brook has an incised, straight channel with a slope of approximately $0.04 \mathrm{ft} / \mathrm{ft}$, an average channel top width of $46 \mathrm{ft}$ and an average bank height of $10 \mathrm{ft}$. The channel bed material ranges from gravel to boulder with a median grain size $\left(\mathrm{D}_{50}\right)$ of $105 \mathrm{~mm}(0.343 \mathrm{ft})$. The geomorphic assessment at the time of the Level I and Level II site visit on October 2, 1995, indicated that the reach was stable.

The Town Highway 47 crossing of Roaring Brook is a 34-ft-long, two-lane bridge consisting of one 31-foot concrete T-beam span (Vermont Agency of Transportation, written communication, March 22, 1995). The opening length of the structure parallel to the bridge face is $29.6 \mathrm{ft}$. The bridge is supported by vertical, concrete abutments with wingwalls. The channel is skewed approximately 10 degrees to the opening while the opening-skew-to-roadway is zero degrees. 
The right abutment footing was exposed from $2 \mathrm{ft}$ to $4 \mathrm{ft}$ and the left abutment footing was exposed $2 \mathrm{ft}$ as observed during the Level I assessment. The scour protection counter measures at the site included type-3 stone fill (less than 48 inches diameter) along the upstream left and right wingwalls and upstream left and right banks and type-2 stone fill (less than 36 inches diameter) along the upstream left and right banks. Additional details describing conditions at the site are included in the Level II Summary and appendices D and E.

Scour depths and recommended rock rip-rap sizes were computed using the general guidelines described in Hydraulic Engineering Circular 18 (Richardson and Davis, 1995) for the 100- and 500-year discharges. Total scour at a highway crossing is comprised of three components: 1) long-term streambed degradation; 2) contraction scour (due to accelerated flow caused by a reduction in flow area at a bridge) and; 3 ) local scour (caused by accelerated flow around piers and abutments). Total scour is the sum of the three components. Equations are available to compute depths for contraction and local scour and a summary of the results of these computations follows.

Contraction scour for all modelled flows ranged from 0.3 to $0.9 \mathrm{ft}$. The worst-case contraction scour occurred at the 500-year discharge. Abutment scour ranged from 4.8 to $7.8 \mathrm{ft}$. The worst-case abutment scour occurred at the 500-year discharge. Additional information on scour depths and depths to armoring are included in the section titled "Scour Results". Scoured-streambed elevations, based on the calculated scour depths, are presented in tables 1 and 2. A cross-section of the scour computed at the bridge is presented in figure 8. Scour depths were calculated assuming an infinite depth of erosive material and a homogeneous particle-size distribution.

It is generally accepted that the Froehlich equation (abutment scour) gives "excessively conservative estimates of scour depths" (Richardson and Davis, 1995, p. 46). Usually, computed scour depths are evaluated in combination with other information including (but not limited to) historical performance during flood events, the geomorphic stability assessment, existing scour protection measures, and the results of the hydraulic analyses. Therefore, scour depths adopted by VTAOT may differ from the computed values documented herein. 


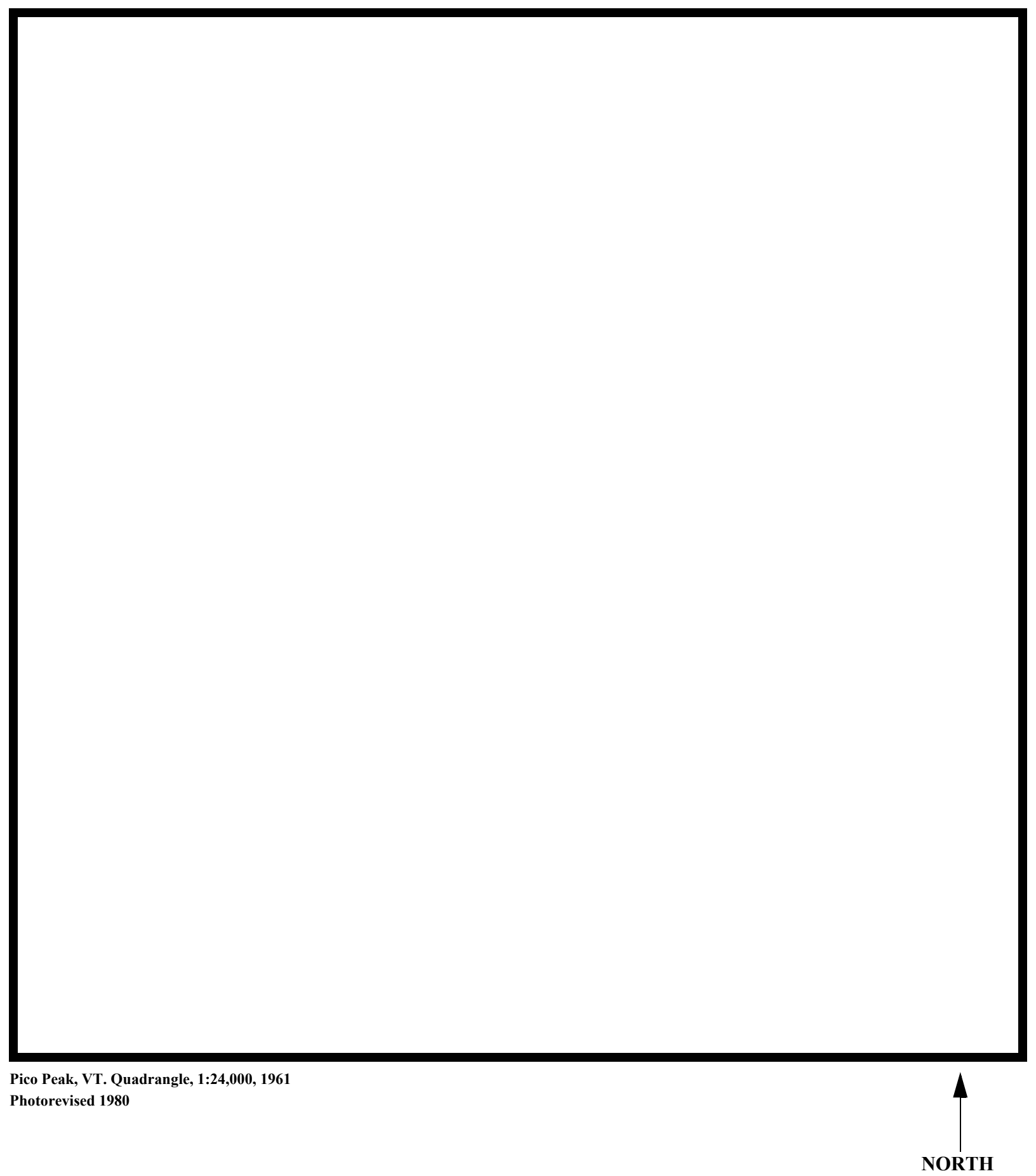

Figure 1. Location of study area on USGS 1:24,000 scale map. 
Figure 2. Location of study area on Vermont Agency of Transportation town highway map. 

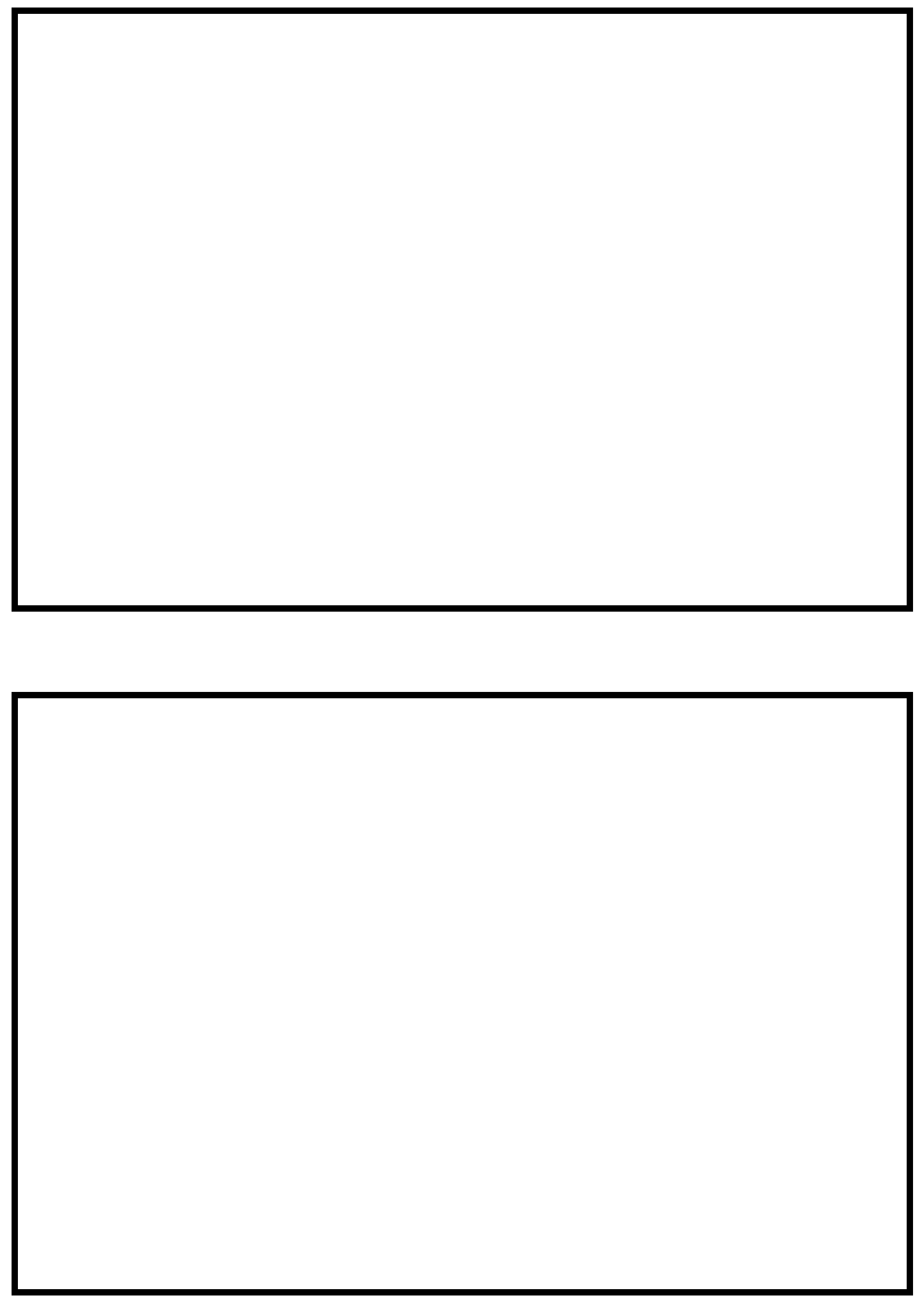

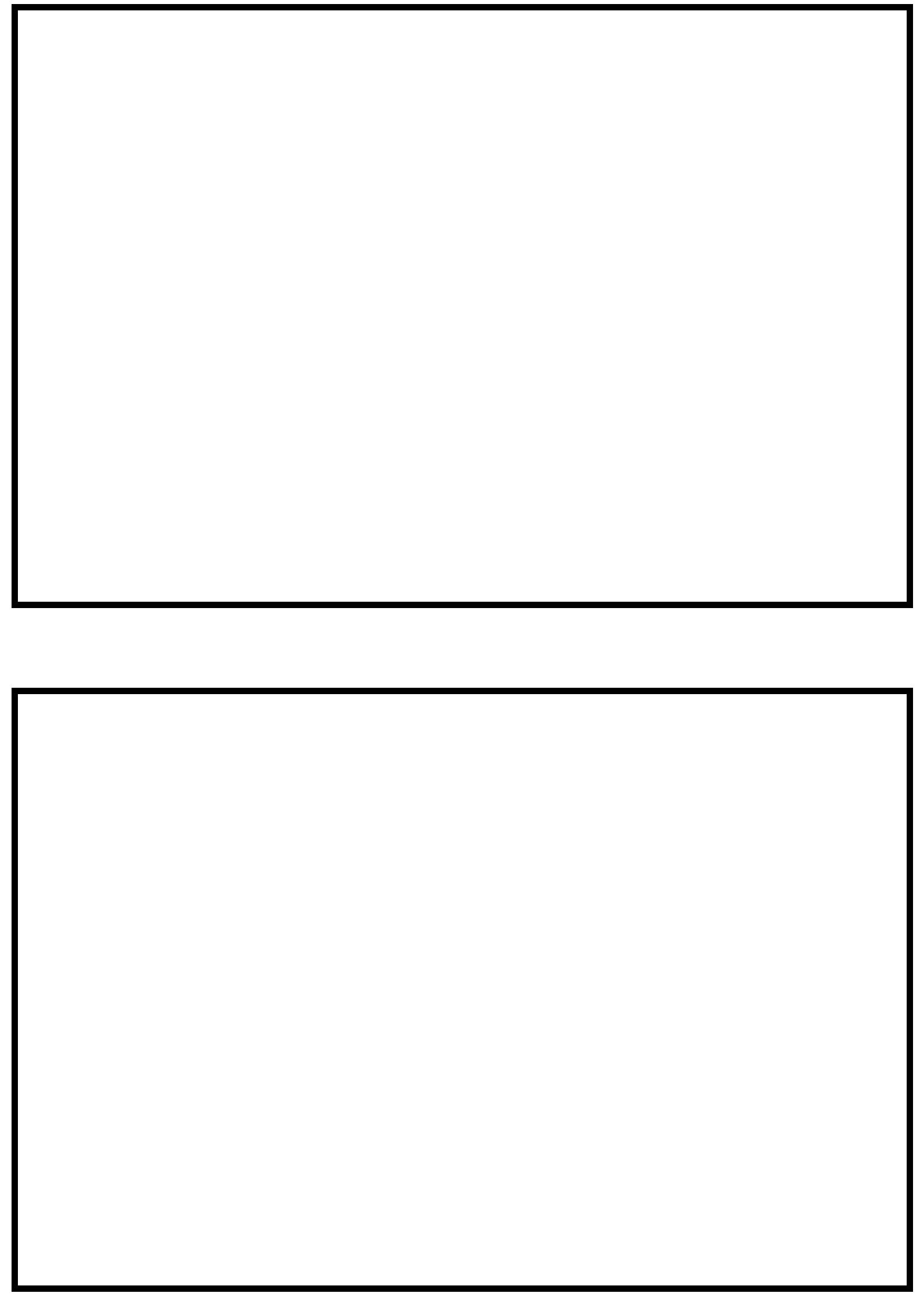


\section{LEVEL II SUMMARY}

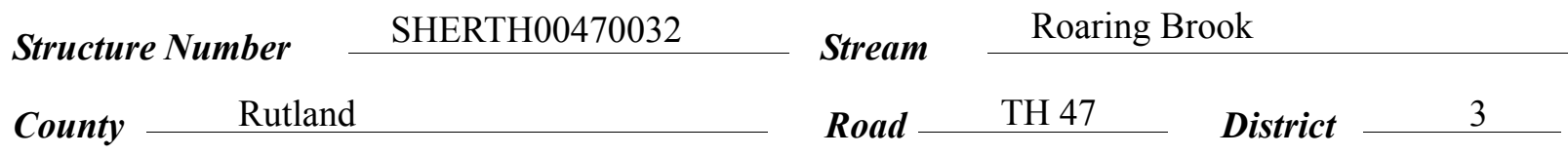

\section{Description of Bridge}

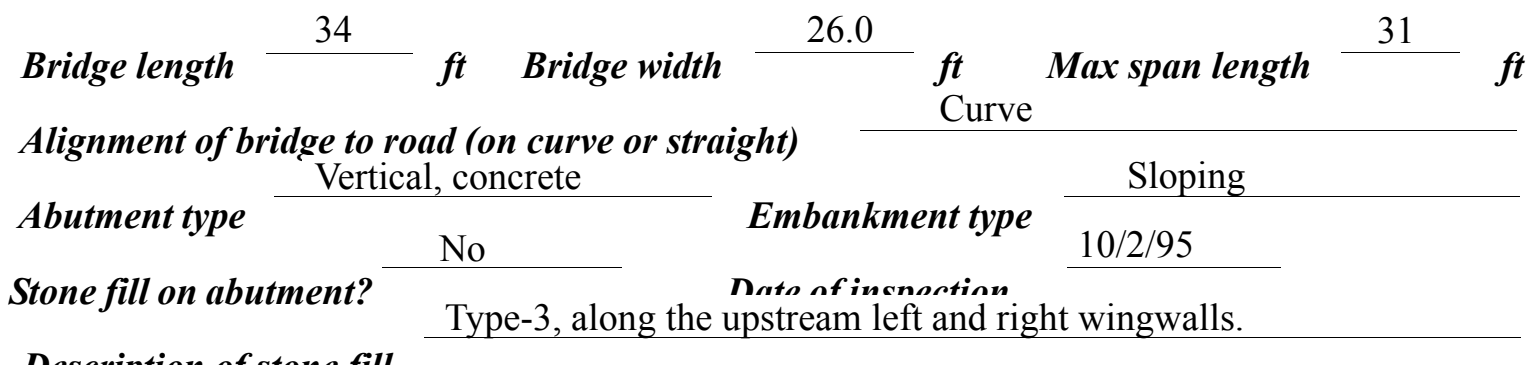

Abutments and wingwalls are concrete. The right

abutment footing is exposed from $2 \mathrm{ft}$ to $4 \mathrm{ft}$ and the left abutment footing is exposed $2 \mathrm{ft}$.

Yes

Is bridge skewed to flood flow according to No ' survey? Angle

Debris accumulation on bridge at time of Level I or Level II site visit:

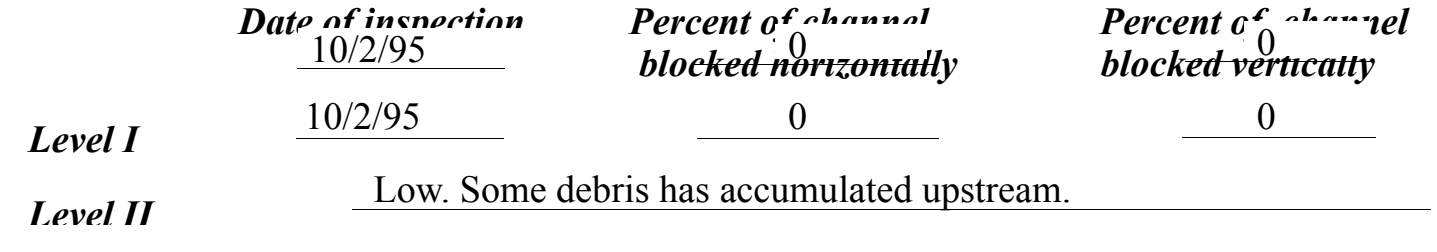

Potential for debris

In front of the downstream left wingwall, the side bar has covered with concrete as of Doscriho anv, foaturos noar ar at tho hridos that mav, affoct flou, (includo ahsorvation dato) $10 / 2 / 95$. 


\section{Description of the Geomorphic Setting}

General topography The channel is located within a moderate relief valley with a flat to slightly irregular narrow flood plain.

Geomorphic conditions at bridge site: downstream (DS), upstream (US)

Date of inspection $\quad 10 / 2 / 95$

DS left: $\quad$ Steep channel bank to a narrow flood plain

DS right: $\quad$ Steep channel bank to a narrow flood plain

US left: $\quad$ Steep channel bank to a moderately sloped overbank

US right: $\quad$ Steep channel bank to a narrow flood plain

\section{Description of the Channel}

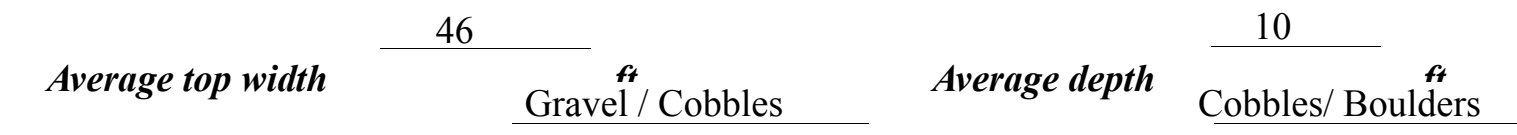

Predominant bed material

Bank material

Straight, perennial but

flashy stream with non-alluvial channel boundaries and narrow side" bars.

$10 / 2 / 95$

Vegetative co 1 Trees and brush

DS left: $\quad$ Trees and brush

DS right: $\quad$ Short grass with a few trees

US left: $\quad$ Short grass with a few trees

US right: $\quad$ Yes

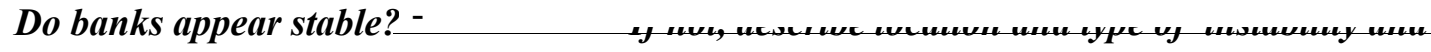

date of observatton.

$2 / 95$.

Describe any obstructions in channel and date of observation. 


\section{Hydrology}

Drainage area $\stackrel{5.55}{\mathrm{mi}^{2}}$

Percentage of drainage area in physiographic provinces: (approximate)

Physiographic province/section

New England/Green Mountain
Percent of drainage area 100

Is drainage area considered rural or urban? Rural Describe any significant

urbanization: There are a couple of houses on the downstream left and right banks.

Is there a USGS gage on the stream of interest?

No

USGS gage description

USGS gage number

Gage drainage area $\mathrm{mi}^{2}$

No

Is there a lake/p -

, ... . . . . . . , , . .

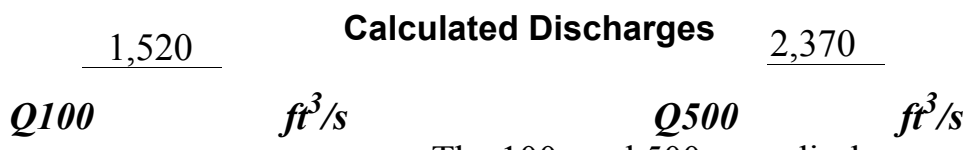

The 100- and 500-year discharges are based on a

drainage area relationship [(5.55/3.0)exp 0.67] with flood frequency estimates for bridge number 26 in Sherburne available from the VTAOT database (written communication, May 1995). Bridge number 26, crossing Falls Brook has a similar drainage area (3.0 square miles) as Roaring Brook. The values used were within a range defined by flood frequency curves developed from several empirical methods (Benson, 1962; Johnson and Tasker, 1974; FHWA, 1983; Potter, 1957a\&b; Talbot, 1887). Each curve was extended graphically to the 500-year event. 


\section{Description of the Water-Surface Profile Model (WSPRO) Analysis}

Datum for WSPRO analysis (USGS survey, sea level, VTAOT plans)

USGS survey

Datum tie between USGS survey and VTAOT plans

None

Description of reference marks used to determine USGS datum. $\quad$ RM1 is a chiseled X on

top of the US end of the right abutment (elev. $498.04 \mathrm{ft}$, arbitrary survey datum). RM2 is a

chiseled X on top of the DS end of the DS left wingwall (elev. $499.11 \mathrm{ft}$, arbitrary survey

datum). RM3 is a nail in a utility pole $4 \mathrm{ft}$ up from the base at the US corner of the intersection of

TH 47 and TH 1 (elev. $507.90 \mathrm{ft}$, arbitrary survey datum).

\section{Cross-Sections Used in WSPRO Analysis}

\begin{tabular}{cccl}
\hline${ }^{1}$ Cross-section & $\begin{array}{c}\text { Section } \\
\text { Reference } \\
\text { Distance } \\
\text { (SRD) } \text { in feet }\end{array}$ & $\begin{array}{c}{ }^{2} \text { Cross-section } \\
\text { development }\end{array}$ & \multicolumn{1}{c}{ Comments } \\
\hline EXITX & -36 & 1 & Exit section \\
FULLV & 0 & 2 & $\begin{array}{l}\text { Downstream Full-valley } \\
\text { section (Templated from } \\
\text { EXITX) }\end{array}$ \\
BRIDG & 0 & 1 & Bridge section \\
RDWAY & 13 & 1 & Road Grade section \\
APPRO & 56 & 1 & Approach section \\
\hline
\end{tabular}

${ }^{1}$ For location of cross-sections see plan-view sketch included with Level I field form, Appendix E. For more detail on how cross-sections were developed see WSPRO input file. 


\section{Data and Assumptions Used in WSPRO Model}

Hydraulic analyses of the reach were done by use of the Federal Highway Administration's WSPRO step-backwater computer program (Shearman and others, 1986, and Shearman, 1990). The analyses reported herein reflect conditions existing at the site at the time of the study. Furthermore, in the development of the model it was necessary to assume no accumulation of debris or ice at the site. Results of the hydraulic model are presented in the Bridge Hydraulic Summary, appendix B, and figure 7.

Channel roughness factors (Manning's " $n$ ") used in the hydraulic model were estimated using field inspections at each cross section following the general guidelines described by Arcement and Schneider (1989). Final adjustments to the values were made during the modelling of the reach. Channel " $\mathrm{n}$ " values for the reach ranged from 0.055 to 0.070 .

Normal depth at the exit section (EXITX) was assumed as the starting water surface. This depth was computed by use of the slope-conveyance method outlined in the user's manual for WSPRO (Shearman, 1990). The slope used was $0.0379 \mathrm{ft} / \mathrm{ft}$, which was estimated from thalweg points surveyed downstream of the bridge.

The approach section (APPRO) was surveyed one bridge length upstream of the upstream face as recommended by Shearman and others (1986). This location provides a consistent method for determining scour variables.

For the 100-year and 500-year discharges, WSPRO assumes critical depth at the bridge section. Supercritical models were developed for these discharges. After analyzing both the supercritical and subcritical profiles for each discharge, it can be determined that the water

surface profile does pass through critical depth within the bridge opening. Thus, the assumptions of critical depth at the bridge are satisfactory solutions. 


\section{Bridge Hydraulics Summary}

$\begin{array}{llll}\text { Average bridge embankment elevation } & 500.0 & f t \\ \text { Average low steel elevation } & 496.5 & \boldsymbol{f t}\end{array}$

100-year discharge $\quad 1,520 \quad \mathrm{ft}^{3} / \mathrm{s}$

Water-surface elevation in bridge opening $\quad 491.7 \quad f t$

Road overtopping? ___ No Discharge over road ___-- $\mathrm{ft}^{3} / \mathrm{s}$

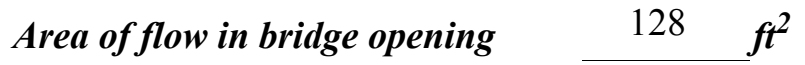

Average velocity in bridge opening $11.9 \mathrm{ft} / \mathrm{s}$

Maximum WSPRO tube velocity at bridge $\quad 15.6 \mathrm{ft} / \mathrm{s}$

Water-surface elevation at Approach section with bridge 494.6

Water-surface elevation at Approach section without bridge $\quad 493.6$

Amount of backwater caused by bridge

$1.0 \quad i$

500-year discharge $\quad 2,370 \quad \mathrm{ft}^{3} / \mathrm{s}$

Water-surface elevation in bridge opening

$493.2 \boldsymbol{f t}$

Road overtopping? ___ No Discharge over road ___ -- $f^{3} / \mathrm{s}$

Area of flow in bridge opening $\quad 173 \quad \mathrm{ft}^{2}$

Average velocity in bridge opening $\quad 13.7 \mathrm{ft} / \mathrm{s}$

Maximum WSPRO tube velocity at bridge 18.2 , 's

Water-surface elevation at Approach section with bridge 496.5

Water-surface elevation at Approach section without bridge $\quad 495.2$

Amount of backwater caused by bridge $\quad 1.3$.t

Incipient overtopping discharge ___ -- $f t^{3} / \mathrm{s}$

Water-surface elevation in bridge opening $\quad--\quad t$

Area of flow in bridge opening _ -- $\mathrm{ft}^{2}$

Average velocity in bridge opening __- $\quad \mathrm{ft} / \mathrm{s}$

Maximum WSPRO tube velocity at bridge _-- $f t / s$

Water-surface elevation at Approach section with bridge

Water-surface elevation at Approach section without bridge

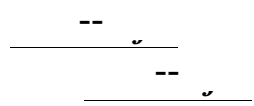

Amount of backwater caused by bridge _ - - it 


\section{Scour Analysis Summary}

\section{Special Conditions or Assumptions Made in Scour Analysis}

Scour depths were computed using the general guidelines described in Hydraulic Engineering Circular 18 (Richardson and Davis, 1995). Scour depths were calculated assuming an infinite depth of erosive material and a homogeneous particle-size distribution. The results of the scour analyses for the 100- and 500-year discharges are presented in tables 1 and 2 and the scour depths are shown graphically in figure 8 .

Contraction scour for the 100-year and 500-year discharges was computed by use of the Laursen clear-water contraction scour equation (Richardson and Davis, 1995, p. 32, equation 20). The streambed armoring depths computed suggest that armoring will not limit the depth of contraction scour.

Abutment scour was computed by use of the Froehlich equation (Richardson and Davis, 1995, p. 48, equation 28). Variables for the Froehlich equation include the Froude number of the flow approaching the embankments, the length of the embankment blocking flow, and the depth of flow approaching the embankment less any roadway overtopping. 


\section{Scour Results}

Contraction scour:

Main channel

Live-bed scour

Clear-water scour

Depth to armoring

Left overbank

Right overbank

Local scour:

Abutment scour

Left abutment

Right abutment

Pier scour

Pier 1

Pier 2

Pier 3
6.1

4.8
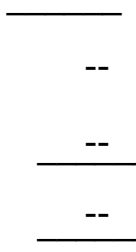

Incipient

500-year overtopping discharge discharge

(Scour depths in feet)

$\begin{array}{lrr}\text { 100-year } & 500-y e a r & \text { overtopping } \\ \text { discharge } & \text { discharge } & \text { discharge }\end{array}$

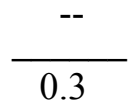

$15.9^{-}$
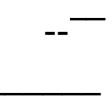

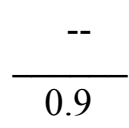

$23.4^{-}$
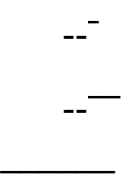

\section{$\sqrt{2}$}




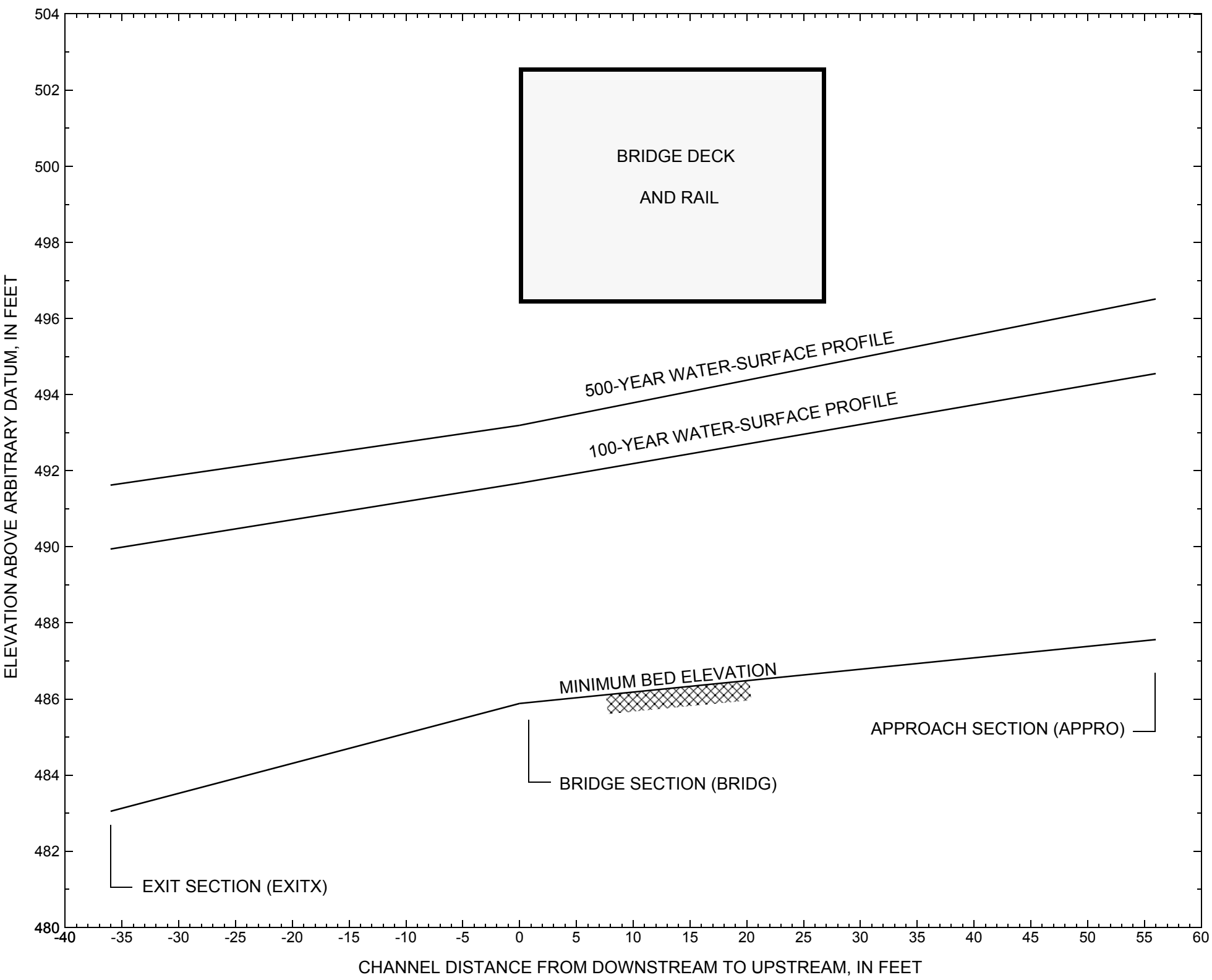

Figure 7. Water-surface profiles for the 100- and 500-year discharges at structure SHERTH00470032 on Town Highway 47, crossing Roaring Brook, Sherburne, Vermont. 


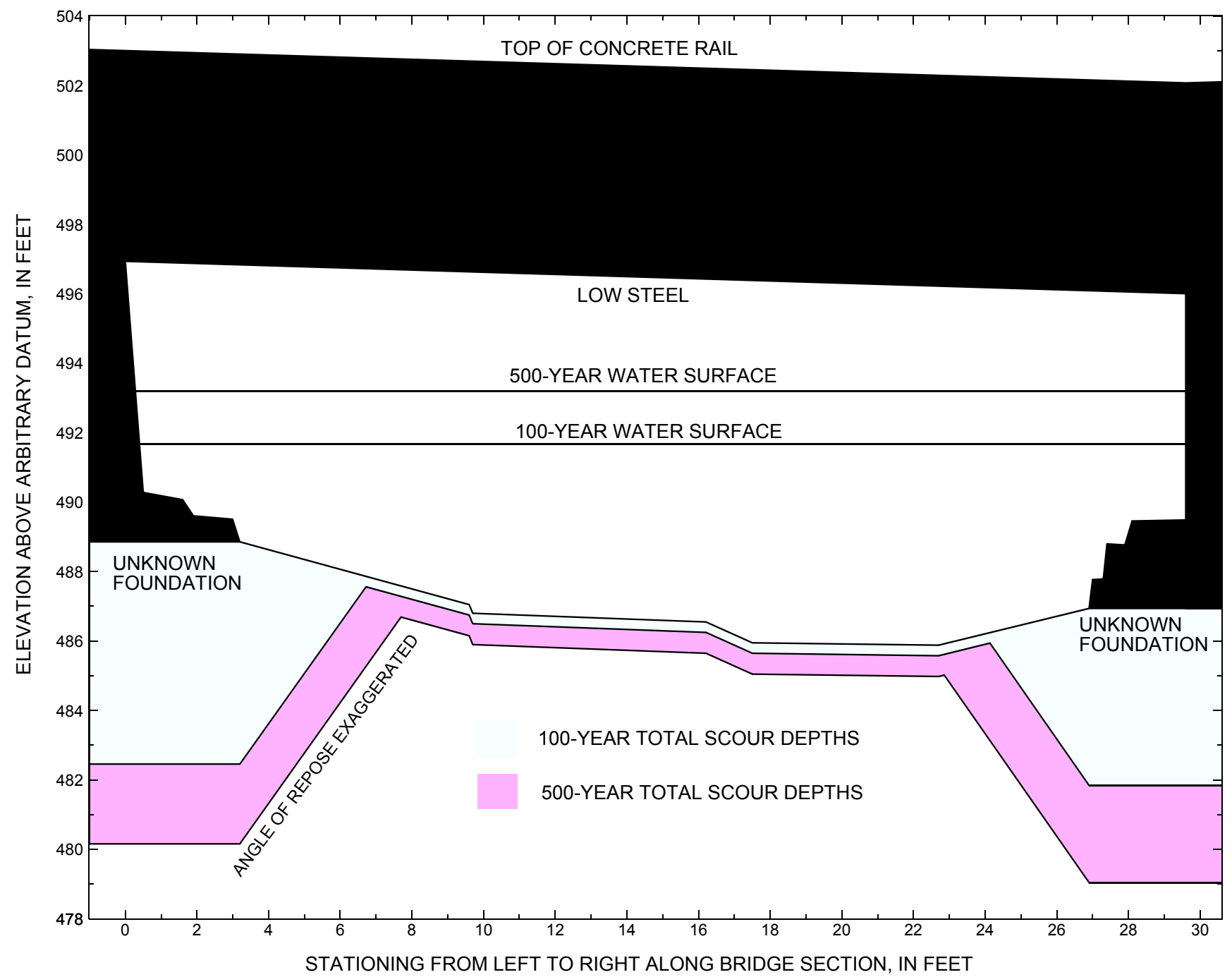

Figure 8. Scour elevations for the 100- and 500-year discharges at structure SHERTH00470032 on Town Highway 47, crossing Roaring Brook, Sherburne, Vermont. 
Table 1. Remaining footing/pile depth at abutments for the 100-year discharge at structure SHERTH00470032 on Town Highway 47, crossing Roaring Brook, Sherburne, Vermont.

[VTAOT, Vermont Agency of Transportation; --, no data]

\begin{tabular}{|c|c|c|c|c|c|c|c|c|c|c|c|}
\hline Description & Station $^{1}$ & $\begin{array}{l}\text { VTAOT } \\
\text { minimum } \\
\text { low-chord } \\
\text { elevation } \\
\text { (feet) }\end{array}$ & $\begin{array}{l}\text { Surveyed } \\
\text { minimum } \\
\text { low-chord } \\
\text { elevation }{ }^{2} \\
\text { (feet) }\end{array}$ & $\begin{array}{c}\text { Bottom of } \\
\text { footing/pile } \\
\text { elevation }{ }^{2} \\
\text { (feet) }\end{array}$ & $\begin{array}{c}\text { Channel } \\
\text { elevation at } \\
\text { abutment/ } \\
\text { pier }^{2} \\
\text { (feet) }\end{array}$ & $\begin{array}{l}\text { Contraction } \\
\text { scour depth } \\
\text { (feet) }\end{array}$ & $\begin{array}{l}\text { Abutment } \\
\text { scour } \\
\text { depth } \\
\text { (feet) }\end{array}$ & $\begin{array}{l}\text { Pier } \\
\text { scour } \\
\text { depth } \\
\text { (feet) }\end{array}$ & $\begin{array}{l}\text { Depth of } \\
\text { total scour } \\
\text { (feet) }\end{array}$ & $\begin{array}{c}\text { Elevation of } \\
\text { scour }^{2} \\
\text { (feet) }\end{array}$ & $\begin{array}{c}\text { Remaining } \\
\text { footing/pile } \\
\text { depth } \\
\text { (feet) }\end{array}$ \\
\hline \multicolumn{12}{|c|}{100 -year discharge is 1,520 cubic-feet per second } \\
\hline Left abutment & 0.0 & -- & 496.9 & -- & 488.9 & 0.3 & 6.1 & -- & 6.4 & 482.5 & -- \\
\hline Right abutment & 29.6 & -- & 496.0 & -- & 486.9 & 0.3 & 4.8 & -- & 5.1 & 481.8 & -- \\
\hline
\end{tabular}

1.Measured along the face of the most constricting side of the bridge.

2.Arbitrary datum for this study.

Table 2. Remaining footing/pile depth at abutments for the 500-year discharge at structure SHERTH00470032 on Town Highway 47, crossing Roaring Brook, Sherburne, Vermont.

[VTAOT, Vermont Agency of Transportation; --, no data]

\begin{tabular}{|c|c|c|c|c|c|c|c|c|c|c|c|}
\hline Description & Station $^{1}$ & $\begin{array}{l}\text { VTAOT } \\
\text { minimum } \\
\text { low-chord } \\
\text { elevation } \\
\text { (feet) }\end{array}$ & $\begin{array}{c}\text { Surveyed } \\
\text { minimum } \\
\text { low-chord } \\
\text { elevation } \\
\text { (feet) }\end{array}$ & $\begin{array}{c}\text { Bottom of } \\
\text { footing/pile } \\
\text { elevation } \\
\text { (feet) }\end{array}$ & $\begin{array}{c}\text { Channel } \\
\text { elevation at } \\
\text { abutment/ } \\
\text { pier }^{2} \\
\text { (feet) }\end{array}$ & $\begin{array}{l}\text { Contraction } \\
\text { scour depth } \\
\text { (feet) }\end{array}$ & $\begin{array}{c}\text { Abutment } \\
\text { scour } \\
\text { depth } \\
\text { (feet) }\end{array}$ & $\begin{array}{l}\text { Pier } \\
\text { scour } \\
\text { depth } \\
\text { (feet) }\end{array}$ & $\begin{array}{l}\text { Depth of } \\
\text { total scour } \\
\text { (feet) }\end{array}$ & $\begin{array}{c}\text { Elevation of } \\
\text { scour }^{2} \\
\text { (feet) }\end{array}$ & $\begin{array}{c}\text { Remaining } \\
\text { footing/pile } \\
\text { depth } \\
\text { (feet) }\end{array}$ \\
\hline \multicolumn{12}{|c|}{500 -year discharge is 2,370 cubic-feet per second } \\
\hline Left abutment & 0.0 & -- & 496.9 & -- & 488.9 & 0.9 & 7.8 & -- & 8.7 & 480.2 & -- \\
\hline Right abutment & 29.6 & -- & 496.0 & -- & 486.9 & 0.9 & 7.0 & -- & 7.9 & 479.0 & -- \\
\hline
\end{tabular}

1.Measured along the face of the most constricting side of the bridge.

2.Arbitrary datum for this study. 


\section{SELECTED REFERENCES}

Arcement, G.J., Jr., and Schneider, V.R., 1989, Guide for selecting Manning's roughness coefficients for natural channels and flood plains: U.S. Geological Survey Water-Supply Paper 2339, 38 p.

Barnes, H.H., Jr., 1967, Roughness characteristics of natural channels: U.S. Geological Survey Water-Supply Paper 1849,213 p.

Benson, M. A., 1962, Factors Influencing the Occurrence of Floods in a Humid Region of Diverse Terrain: U.S. Geological Survey WaterSupply Paper 1580-B, 64 p.

Brown, S.A. and Clyde, E.S., 1989, Design of riprap revetment: Federal Highway Administration Hydraulic Engineering Circular No. 11, Publication FHWA-IP-89-016, 156 p.

Federal Highway Administration, 1983, Runoff estimates for small watersheds and development of sound design: Federal Highway Administration Report FHWA-RD-77-158.

Federal Highway Administration, 1993, Stream Stability and Scour at Highway Bridges: Participant Workbook: Federal Highway Administration Report FHWA-HI-91-011.

Froehlich, D.C., 1989, Local scour at bridge abutments in Ports, M.A., ed., Hydraulic Engineering--Proceedings of the 1989 National Conference on Hydraulic Engineering: New York, American Society of Civil Engineers, p. 13-18.

Hayes, D.C.,1993, Site selection and collection of bridge-scour data in Delaware, Maryland, and Virginia: U.S. Geological Survey WaterResources Investigation Report 93-4017, 23 p.

Interagency Advisory Committee on Water Data, 1982, Guidelines for determining flood flow frequency: U.S. Geological Survey, Bulletin 17B of the Hydrology Subcommittee, 190 p.

Johnson, C.G. and Tasker, G.D.,1974, Progress report on flood magnitude and frequency of Vermont streams: U.S. Geological Survey OpenFile Report 74-130, 37 p.

Lagasse, P.F., Schall, J.D., Johnson, F., Richardson, E.V., Chang, F., 1995, Stream Stability at Highway Structures: Federal Highway Administration Hydraulic Engineering Circular No. 20, Publication FHWA-IP-90-014, 144 p.

Laursen, E.M., 1960, Scour at bridge crossings: Journal of the Hydraulics Division, American Society of Civil Engineers, v. 86, no. HY2, p. 39-53.

Potter, W. D., 1957a, Peak rates of runoff in the Adirondack, White Mountains, and Maine woods area, Bureau of Public Roads

Potter, W. D., 1957b, Peak rates of runoff in the New England Hill and Lowland area, Bureau of Public Roads

Richardson, E.V. and Davis, S.R., 1995, Evaluating scour at bridges: Federal Highway Administration Hydraulic Engineering Circular No. 18, Publication FHWA-IP-90-017, 204 p.

Richardson, E.V., Simons, D.B., and Julien, P.Y., 1990, Highways in the river environment: Federal Highway Administration Publication FHWA-HI-90-016.

Ritter, D.F., 1984, Process Geomorphology: W.C. Brown Co., Debuque, Iowa, 603 p.

Shearman, J.O., 1990, User's manual for WSPRO--a computer model for water surface profile computations: Federal Highway Administration Publication FHWA-IP-89-027, 187 p.

Shearman, J.O., Kirby, W.H., Schneider, V.R., and Flippo, H.N., 1986, Bridge waterways analysis model; research report: Federal Highway Administration Publication FHWA-RD-86-108, 112 p.

Talbot, A.N., 1887, The determination of water-way for bridges and culverts.

U.S. Geological Survey, 1961, Pico Peak, Vermont 7.5 Minute Series quadrangle map: U.S. Geological Survey Topographic Maps, Photorevised 1980, Scale 1:24,000. 


\section{APPENDIX A: \\ WSPRO INPUT FILE}




\section{WSPRO INPUT FILE}

*

XS

GR

GR

GR

GR

$\mathrm{N}$

*

XS

*

*

BR

GR

GR

GR

GR

GR

GR

*

CD

$\mathrm{N}$

*

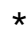

$\mathrm{XR}$

GR

GR

GR

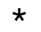

*

AS

GR

GR

GR

GR

GR

$\mathrm{N}$

HP 1 BRIDG

HP 2 BRIDG

HP 1 APPRO

HP 2 APPRO

*

HP 1 BRIDG

HP 2 BRIDG

$\mathrm{HP} 1 \mathrm{APPRO}$

HP 2 APPRO

*

EX
U.S. Geological Survey WSPRO Input File sher032.wsp

Hydraulic analysis for structure SHERTH00470032 Date: 26-NOV-97

Bridge 32 on River Road over Roaring Brook in Sherburne, VT by MAI

$\begin{array}{lllllllllllllllllllll}6 & 29 & 30 & 552 & 553 & 551 & 5 & 16 & 17 & 13 & 3 & * & 15 & 14 & 23 & 21 & 11 & 12 & 4 & 7 & 3\end{array}$

$1520.0 \quad 2370.0$

$0.0379 \quad 0.0379$

$\operatorname{EXITX} \quad-36$

$\begin{array}{rrr}-116.9,507.51 & -68.8,502.34 & -55.7,499.83 \\ 0.0,498.11 & 14.7,485.33 & 20.6,484.22 \\ 27.5,483.38 & 31.8,483.56 & 32.1,484.23 \\ 46.3,497.32 & 52.2,498.28 & 84.5,498.78 \\ 0.070 & & \end{array}$

$-15.9,499.53$

$24.4,483.05$

$36.4,486.36$

$1.6,490.07$

$1.9,489.61$

$9.6,487.05 \quad 9.7,486.80$

$22.7,485.88 \quad 26.9,486.94$

$27.3,487.79 \quad 27.4,488.80$

$29.6,489.49 \quad 29.6,496.01$
$17.5,485.95$

$27.0,487.77$

$28.1,489.46$

0.0

BRTYPE BRWDTH

133.7 * *

0.055

$33.7 * *$

WWANG

45.6

WWWID

6.8

$\mathrm{SRD}$

EMBWID

26.0

$-118.8,506.96$

$0.0,500.39$

$58.8,498.88$

$150.5,495.24$

APPRO 56

$$
-75.5,508.06
$$

$-11.1,496.60$

$-63.4,504.76$

$0.0,490.33$

$8.8,487.56$

$20.6,489.11$

$71.8,499.20$

0.065

$11.7,487.57$

$23.6,490.36$

$127.8,499.21$

491.671491 .67

$491.67 * * 1520$

494.551494 .55

$494.55 * * 1520$

493.191493 .19

$493.19 * * 2370$

496.511496 .51

$496.51 * * 2370$

$$
-5
$$

$-50.7,502.85$

$4.2,488.71$

$13.6,488.23$

$32.3,498.46$
$-16.5,501.13$

$34.3,499.61$
$-17.4,500.41$

$4.3,487.67$

$17.1,488.14$

$48.0,499.34$ 


\section{APPENDIX B: \\ WSPRO OUTPUT FILE}




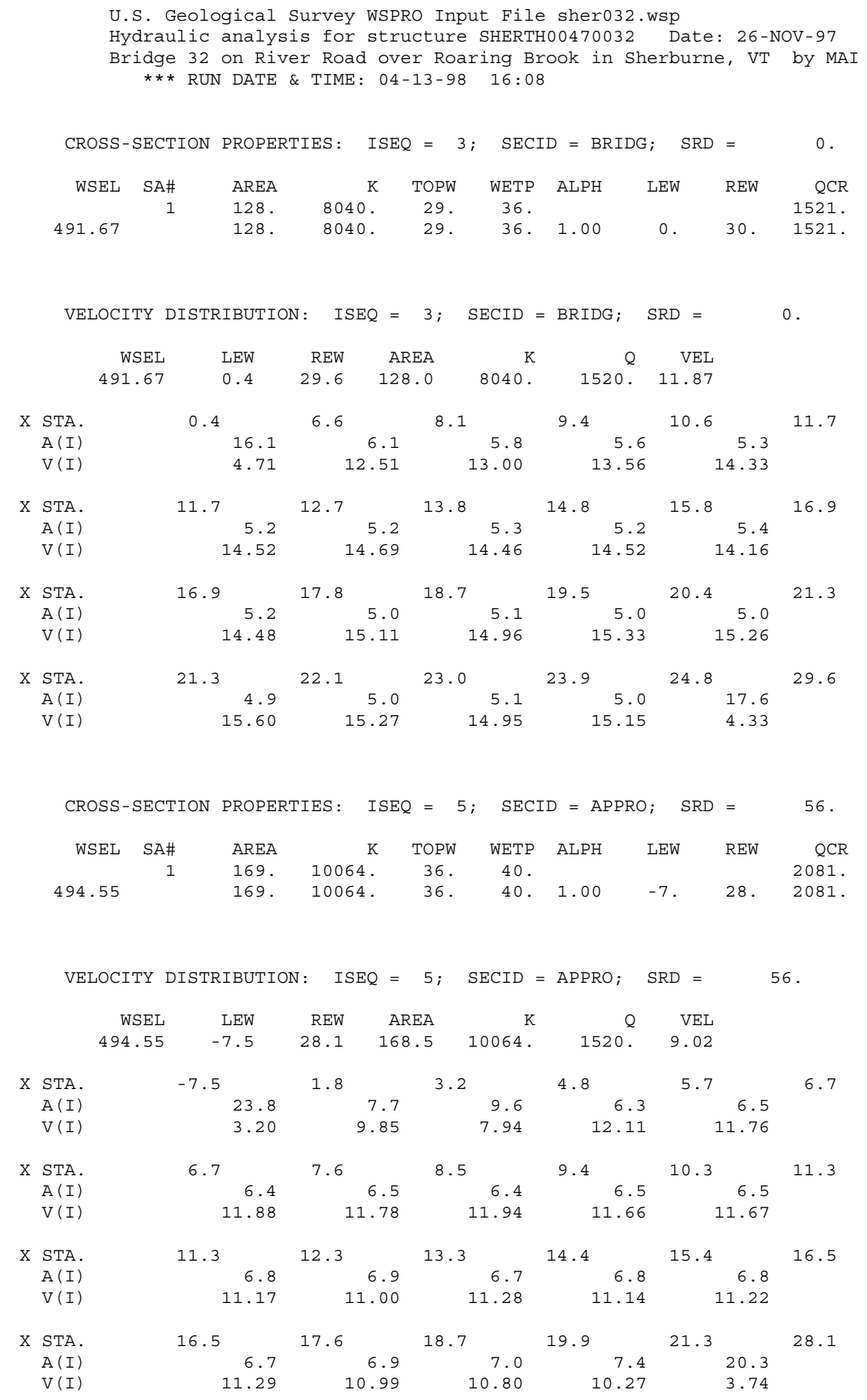


WSPRO OUTPUT FILE (continued)

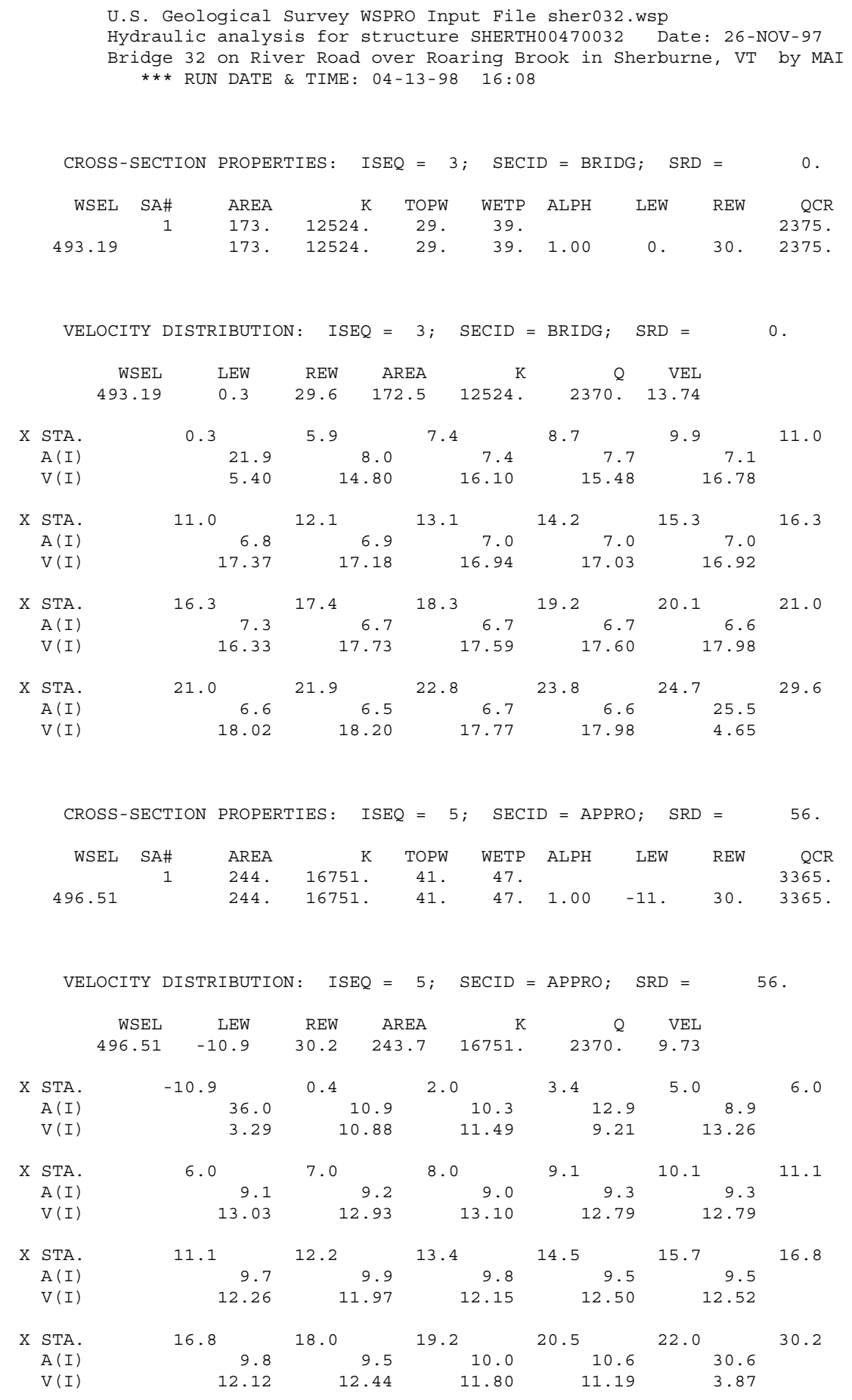


WSPRO OUTPUT FILE (continued)

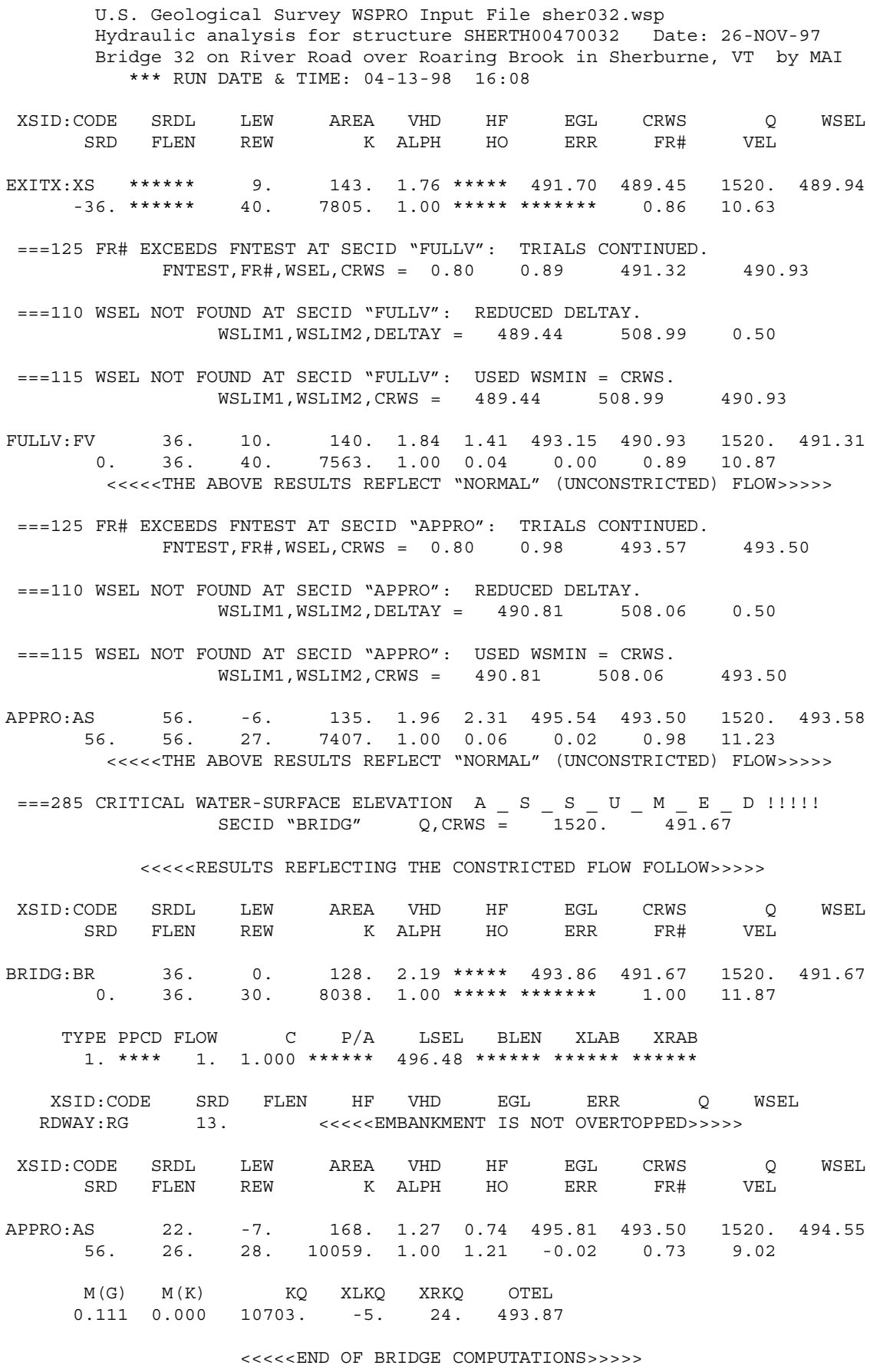

FIRST USER DEFINED TABLE.

\begin{tabular}{|c|c|c|c|c|c|c|c|c|}
\hline XSID : CODE & $\mathrm{SRD}$ & LEW & REW & Q & K & AREA & VEL & WSEL \\
\hline EXITX:XS & -36 & 9. & 40 . & 1520. & 7805 . & 143. & 10.63 & 489.94 \\
\hline FULLV : FV & 0 . & 10. & 40. & 1520. & 7563. & 140. & 10.87 & 491.31 \\
\hline BRIDG : BR & 0 . & 0 & 30. & 1520. & 8038 . & 128. & 11.87 & 491.67 \\
\hline RDWAY : RG & \multicolumn{3}{|c|}{$13 . * * * * \star * * * \star * * * * *$} & \multicolumn{3}{|c|}{$0 . * * * * * * * * * * * * * * * * * *$} & \multicolumn{2}{|c|}{$1.00 * * * * * * * *$} \\
\hline APPRO : AS & 56. & -7 & 28 & 1520. & 10059 . & 168. & 9.02 & 494.55 \\
\hline XSID : CODE & XLKQ & XRKQ & & & & & & \\
\hline APPRO: AS & -5 . & 24 & 1070 & & & & & \\
\hline
\end{tabular}

SECOND USER DEFINED TABLE.

$\begin{array}{lrrrrrrrrr}\text { XSID:CODE } & \text { CRWS } & \text { FR\# } & \text { YMIN } & \text { YMAX } & \text { HF } & \text { HO } & \text { VHD } & \text { EGL } & \text { WSEL } \\ \text { EXITX:XS } & 489.45 & 0.86 & 483.05 & 507.51 * * * * * * * * * * * & 1.76 & 491.70 & 489.94 \\ \text { FULLV:FV } & 490.93 & 0.89 & 484.53 & 508.99 & 1.41 & 0.04 & 1.84 & 493.15 & 491.31 \\ \text { BRIDG :BR } & 491.67 & 1.00 & 485.88 & 496.94 * * * * * * * * * * * * & 2.19 & 493.86 & 491.67 \\ \text { RDWAY:RG } & * * * * * * * * * * * * * * * & 498.88 & 506.96 * * * * * * * * * * * * * * * * * * * * * * * * * * * * * * \\ \text { APPRO:AS } & 493.50 & 0.73 & 487.56 & 508.06 & 0.74 & 1.21 & 1.27 & 495.81 & 494.55\end{array}$


WSPRO OUTPUT FILE (continued)

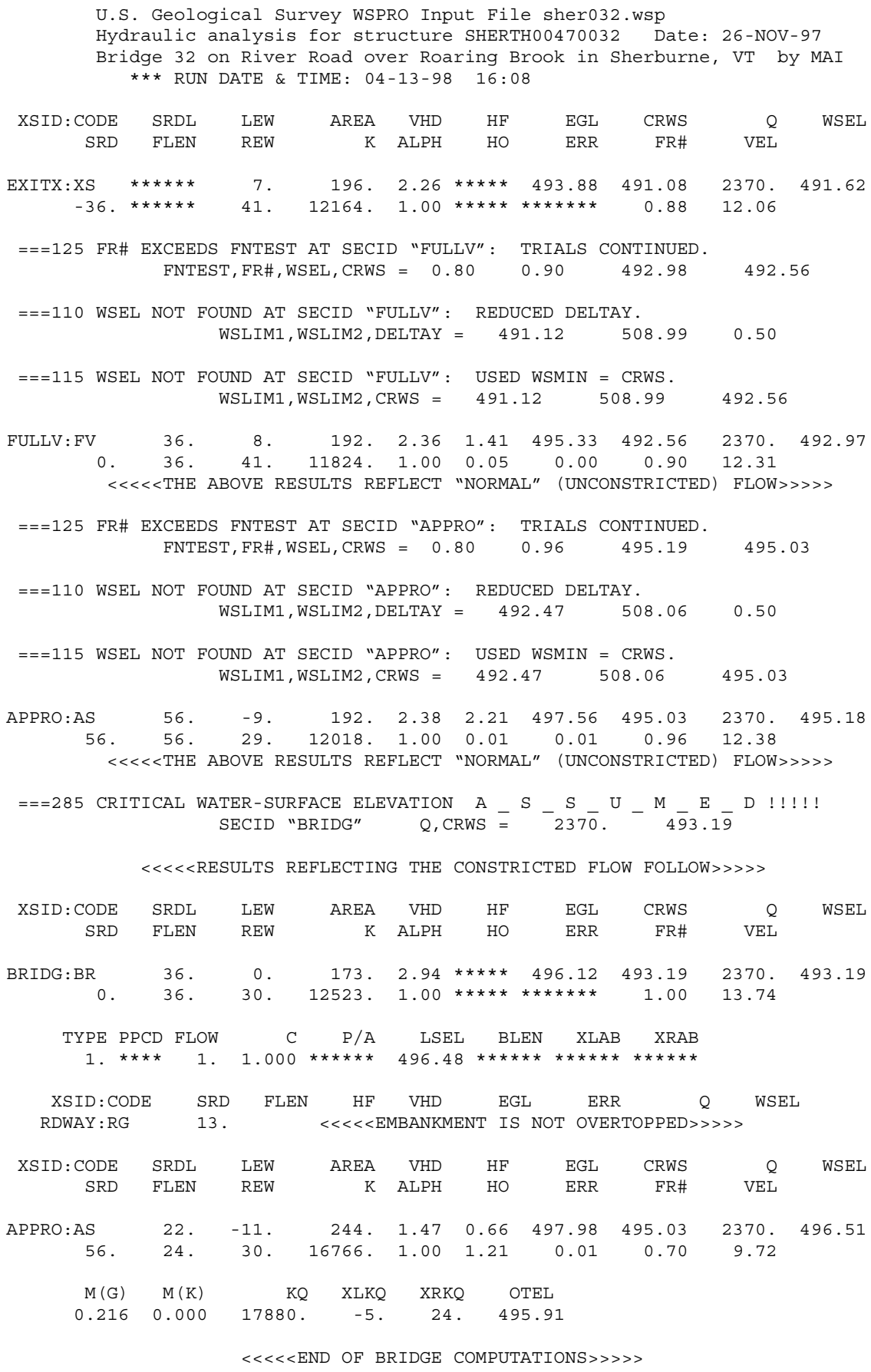

FIRST USER DEFINED TABLE.

\begin{tabular}{|c|c|c|c|c|c|c|c|c|}
\hline XSID : CODE & SRD & LEW & REW & Q & $\mathrm{K}$ & AREA & VEL & WSEL \\
\hline EXITX:XS & -36 & 7. & 41. & 2370 . & 12164 . & 196. & 12.06 & 491.62 \\
\hline FULLV: FV & 0 & 8 . & 41. & 2370 . & 11824 . & 192. & 12.31 & 492.97 \\
\hline BRIDG : BR & 0 & 0 & 30. & 2370 . & 12523. & 173. & 13.74 & 493.19 \\
\hline RDWAY : RG & \multicolumn{3}{|c|}{$13 . * * * * * * * * * * * * * *$} & \multicolumn{3}{|c|}{ 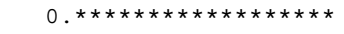 } & \multicolumn{2}{|c|}{$1.00 * * * * * * * *$} \\
\hline APPRO : AS & 56. & -11 & 30. & 2370 . & 16766 & 244 & 9.72 & 496.51 \\
\hline XSID : CODE & XLKQ & $\mathrm{XRKQ}$ & & & & & & \\
\hline APPRO : AS & -5 & 24 & 1788 & & & & & \\
\hline
\end{tabular}

SECOND USER DEFINED TABLE.

$\begin{array}{lrrrrrrrrr}\text { XSID : CODE } & \text { CRWS } & \text { FR\# } & \text { YMIN } & \text { YMAX } & \text { HF } & \text { HO } & \text { VHD } & \text { EGL } & \text { WSEL } \\ \text { EXITX:XS } & 491.08 & 0.88 & 483.05 & 507.51 * * * * * * * * * * * & 2.26 & 493.88 & 491.62 \\ \text { FULLV:FV } & 492.56 & 0.90 & 484.53 & 508.99 & 1.41 & 0.05 & 2.36 & 495.33 & 492.97 \\ \text { BRIDG: BR } & 493.19 & 1.00 & 485.88 & 496.94 * * * * * * * * * * * & 2.94 & 496.12 & 493.19 \\ \text { RDWAY: RG } & * * * * * * * * * * * * * * & 498.88 & 506.96 * * * * * * * * * * * * * * * * * * * * * * * * * * * * \\ \text { APPRO:AS } & 495.03 & 0.70 & 487.56 & 508.06 & 0.66 & 1.21 & 1.47 & 497.98 & 496.51\end{array}$




\section{APPENDIX C:}

\section{BED-MATERIAL PARTICLE-SIZE DISTRIBUTION}




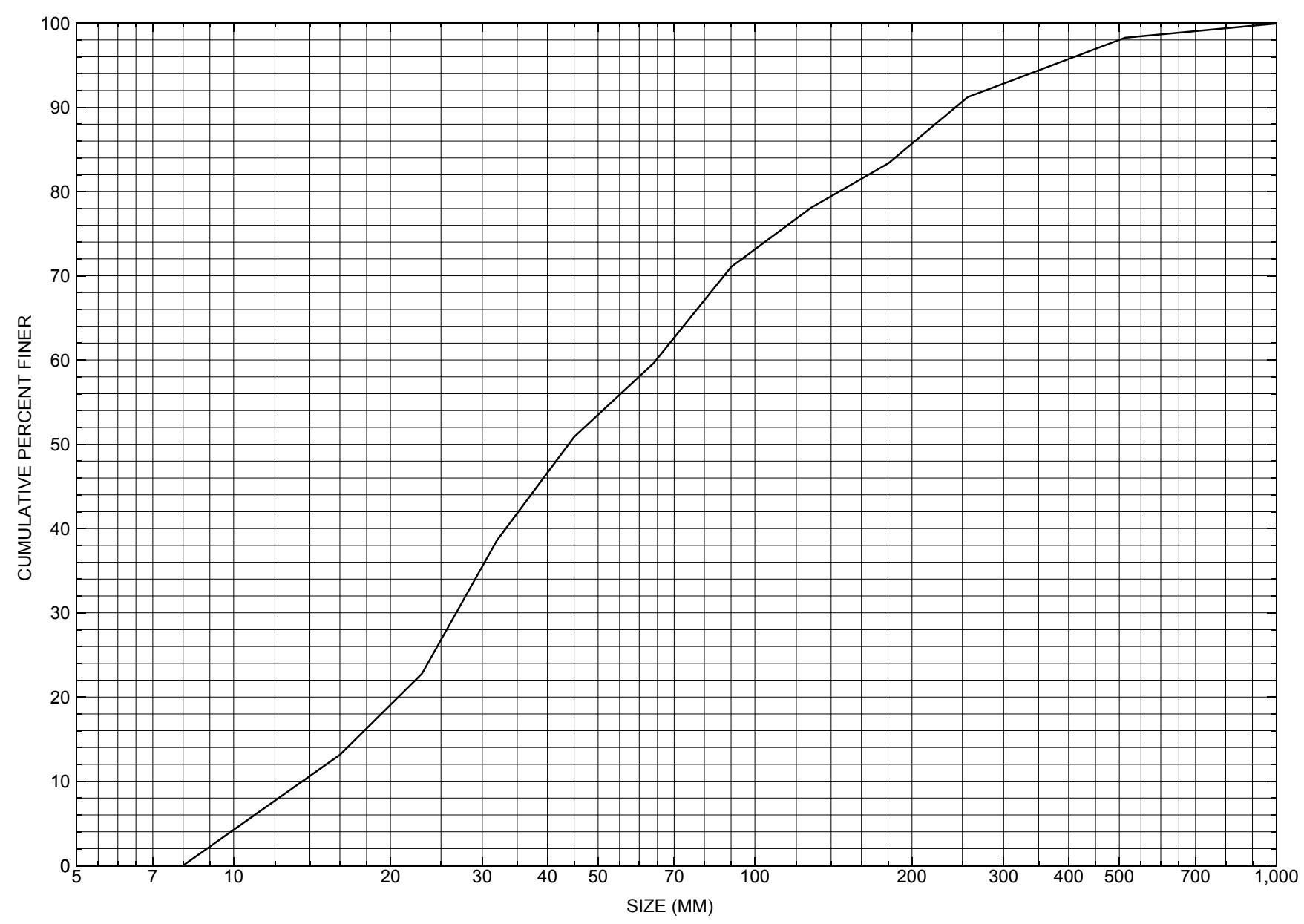

Appendix C. Bed material particle-size distribution for a pebble count in the channel approach of structure SHERTH00470032, in Sherburne, Vermont. 


\section{APPENDIX D: \\ HISTORICAL DATA FORM}




\section{Structure Number SHERTH00470032}

\section{General Location Descriptive}

Data collected by (First Initial, Full last name) $\underline{\mathbf{E}}$. Boehmler

Date $(M M / D D / Y Y) \_\mathbf{0 3} / \underline{22} / \underline{95}$

Highway District Number (I - 2; nn) $\mathbf{0 3}$

Town (FIPS place code; I - 4; nnnnn) $\mathbf{6 4 8 2 5}$

Waterway ( $($ - 6) Roaring Brook

Route Number $\underline{\text { TH047 }}$

Topographic Map Pico.Peak

Latitude (I - 16; nnnn.n) 433395
County (FIPS county code; I - 3; nnn)

Mile marker (I - 11; nnn.nnn) $\mathbf{0 0 0 0 0 0}$

Road Name (I - 7): River Road

Vicinity (I - 9) $\mathbf{0 . 0 2}$ miles to the jet with TH1

Hydrologic Unit Code: $\mathbf{0 1 0 8 0 1 0 6}$

Longitude (i - 17; nnnnn.n) $\mathbf{7 2 4 6 4}$

\section{Select Federal Inventory Codes}

FHWA Structure Number (I - 8) $\mathbf{1 0 1 1 2 1 0 0 3 2 1 1 2 1}$

Maintenance responsibility $(I-21 ; n n) \_\mathbf{0 3}$

Year built (I - 27; YYYY) 1925

Average daily traffic, ADT (I - 29; nnnnnn) 000060

Year of ADT (I - 30; YY) $\mathbf{9 3}$

Opening skew to Roadway $(I-34 ; n n) \quad \mathbf{0 0}$

Operational status $(I-41 ; X) \quad \mathbf{A}$

Structure type (I - 43; nnn) 104

Approach span structure type $(I-44 ; n n n) \quad \mathbf{0 0 0}$

Number of spans (I - 45; nnn) $\underline{\mathbf{0 0 1}}$

Number of approach spans (I - 46; nnnn) $\mathbf{0 0 0 0}$

Comments:

The structural inspection report of $7 / 5 / 93$ indicates the structure is a concrete T-beam type bridge with an asphalt roadway surface. The abutment walls and wingwalls are concrete. The exposed footings of both abutments are reported as having been patched recently. There is some stone and boulder fill noted in front of the each abutment and wingwall, and along the channel banks. The report further indicates the stone fill noted on the right abutment has been partially eroded away from the wall. While the footings are exposed, undermining and settling are reported as not apparent. 


\section{Bridge Hydrologic Data}

Is there hydrologic data available? $\underline{\mathbf{N}}$ if No, type ctrl-n $h \quad$ VTAOT Drainage area $\left(m i^{2}\right)$ : -

Terrain character:

Stream character \& type: -

Streambed material:

Discharge Data (cfs):

$$
\begin{aligned}
& Q_{2.33}- \\
& Q_{50}-
\end{aligned}
$$

Record flood date $(M M / D D / Y Y)$ :

Estimated Discharge (cfs): Ice conditions (Heavy, Moderate, Light) : -

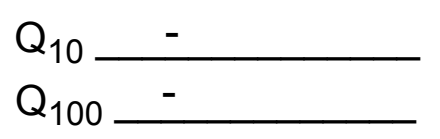

$$
\begin{aligned}
& Q_{25}- \\
& Q_{500}-
\end{aligned}
$$

Water surface elevation $(f t):-$

The stage increases to maximum highwater elevation (Rapidly, Not rapidly):

The stream response is (Flashy, Not flashy):

Describe any significant site conditions upstream or downstream that may influence the stream's stage: -

Watershed storage area (in percent): _ _ \%

The watershed storage area is: - (1-mainly at the headwaters; 2- uniformly distributed; 3-immediatly upstream oi the site)

Water Surface Elevation Estimates for Existing Structure:

\begin{tabular}{|l|l|l|l|l|l|}
\hline Peak discharge frequency & $Q_{2.33}$ & $Q_{10}$ & $Q_{25}$ & $Q_{50}$ & $Q_{100}$ \\
Water surface elevation (ft)) & - & - & - & - & - \\
Velocity (ft/sec) & - & - & - & - & - \\
\hline
\end{tabular}

Long term stream bed changes: -

Is the roadway overtopped below the $\mathrm{Q}_{100}$ ? (Yes, No, Unknown): $\mathbf{U}$ Frequency: Relief Elevation (ft): Discharge over roadway at $Q_{100}\left(f^{3} / \mathrm{sec}\right)$ :

Are there other structures nearby? (Yes, No, Unknown): $\underline{\mathbf{U}}$ Upstream distance (miles): Town: If No or Unknown, type ctrl-n os Highway No. : Structure No. : Year Built:

Clear span (ft): Clear Height $(f t)$ : Full Waterway $\left(f^{2}\right)$ : 
Downstream distance (miles): Town: Year Built:

Highway No. : Structure No. : Structure Type:

Clear span (ft): Clear Height $(f t)$ : Full Waterway $\left(f^{2}\right)$ : -

Comments:

\section{USGS Watershed Data}

Watershed Hydrographic Data

Drainage area $(D A)$

Watershed storage (ST) $\mathrm{mi}^{2}$ Lake/pond/swamp area $\mathrm{mi}^{2}$

Bridge site elevation $1220 \quad \mathrm{ft}$ $\%$

Main channel length 5.51 mi $10 \%$ channel length elevation $\mathbf{1 4 6 0}$ $\mathrm{ft} \quad 85 \%$ channel length elevation 2700 $\mathrm{ft}$ Main channel slope $(S) \quad \mathbf{3 0 0 . 0 7} \mathrm{ft} / \mathrm{mi}$

Watershed Precipitation Data

Average site precipitation in Average headwater precipitation in

Maximum 2yr-24hr precipitation event $(124,2)$ in

Average seasonal snowfall (Sn) $\mathrm{ft}$ 


\section{Bridge Plan Data}

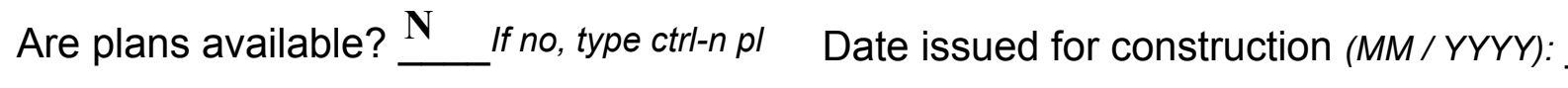

Project Number

Minimum channel bed elevation:

Low superstructure elevation: USLAB DSLAB USRAB DSRAB Benchmark location description:

NO BENCHMARK INFORMATION

Reference Point (MSL, Arbitrary, Other): Datum (NAD27, NAD83, Other):

Foundation Type: 4

If 1 : Footing Thickness

If 2: Pile Type:

If 3: Footing bottom elevation:

Is boring information available? $\mathbf{N}$

Foundation Material Type: $\mathbf{3}$

(1-Spreadfooting; 2-Pile; 3- Gravity; 4-Unknown)

Footing bottom elevation: -

Briefly describe material at foundation bottom elevation or around piles:

NO FOUNDATION MATERIAL INFORMATION 


\section{Cross-sectional Data}

Is cross-sectional data available? $\underline{\mathbf{N}}$ If no, type ctrl-n xs

Source (FEMA, VTAOT, Other)? -

Comments: NO CROSS SECTION INFORMATION

\begin{tabular}{|l|l|l|l|l|l|l|l|l|l|l|l|}
\hline Station & - & - & - & - & - & - & - & - & - & - & - \\
\hline Feature & - & - & - & - & - & - & - & - & - & - & - \\
\hline $\begin{array}{l}\text { Low chord } \\
\text { elevation }\end{array}$ & - & - & - & - & - & - & - & - & - & - & - \\
\hline $\begin{array}{l}\text { Bed } \\
\text { elevation }\end{array}$ & - & - & - & - & - & - & - & - & - & - & - \\
\hline $\begin{array}{l}\text { Low chord } \\
\text { to bed }\end{array}$ & - & - & - & - & - & - & - & - & - & - & - \\
\hline Station & - & - & - & - & - & - & - & - & - & - & - \\
\hline Feature & - & - & - & - & - & - & - & - & - & - & - \\
\hline $\begin{array}{l}\text { Low chord } \\
\text { elevation }\end{array}$ & - & - & - & - & - & - & - & - & - & - & - \\
\hline $\begin{array}{l}\text { Bed } \\
\text { elevation }\end{array}$ & - & - & - & - & - & - & - & - & - & - & - \\
\hline $\begin{array}{l}\text { Low chord } \\
\text { to bed }\end{array}$ & - & - & - & - & - & - & - & - & - & - & - \\
\hline
\end{tabular}

Source (FEMA, VTAOT, Other)?

Comments: NO CROSS SECTION INFORMATION

\begin{tabular}{|l|l|l|l|l|l|l|l|l|l|l|l|}
\hline Station & - & - & - & - & - & - & - & - & - & - & - \\
\hline Feature & - & - & - & - & - & - & - & - & - & - & - \\
\hline $\begin{array}{l}\text { Low chord } \\
\text { elevation }\end{array}$ & - & - & - & - & - & - & - & - & - & - & - \\
\hline $\begin{array}{l}\text { Bed } \\
\text { elevation }\end{array}$ & - & - & - & - & - & - & - & - & - & - & - \\
\hline $\begin{array}{l}\text { Low chord } \\
\text { to bed }\end{array}$ & - & - & - & - & - & - & - & - & - & - & - \\
\hline Station & - & - & - & - & - & - & - & - & - & - & - \\
\hline Feature & - & - & - & - & - & - & - & - & - & - & - \\
\hline $\begin{array}{l}\text { Low chord } \\
\text { elevation }\end{array}$ & - & - & - & - & - & - & - & - & - & - & - \\
\hline $\begin{array}{l}\text { Bed } \\
\text { elevation }\end{array}$ & - & - & - & - & - & - & - & - & - & - & - \\
\hline $\begin{array}{l}\text { Low chord } \\
\text { to bed }\end{array}$ & - & - & - & - & - & - & - & - & - & - & - \\
\hline
\end{tabular}




\section{APPENDIX E: \\ LEVEL I DATA FORM}


U. S. Geological Survey

Bridge Field Data Collection and Processing Form

Qa/Qc Check by: $\mathbf{C G}$ Date: $\mathbf{0 2 / 1 6 / 9 6}$

\section{Structure Number}

SHERTH00470032 Date: $\underline{\mathbf{0 2} / \mathbf{1 6} / 96}$

\section{A. General Location Descriptive}

1. Data collected by (First Initial, Full last name) $\underline{\mathbf{T}}$. Severance

Date $(M M / D D / Y Y)$

10 / 02 / 1995

2. Highway District Number $\mathbf{0 3}$

County Rutland (021)

Mile marker -

Waterway (I - 6) Roaring brook

Route Number TH047

Town Sherburne (64825)

Road Name River Road

3. Descriptive comments:

Hydrologic Unit Code: $\mathbf{0 1 0 8 0 1 0 6}$

This site is located 0.02 miles from the junction with Town Highway 1 and $100 \mathrm{ft}$ downstream from US 4.

\section{B. Bridge Deck Observations}
4. Surface cover... LBUS 4
RBUS 4
LBDS 6
RBDS 6
Overall 6

(2b us,ds,lb,rb: 1- Urban; 2- Suburban; 3- Row crops; 4- Pasture; 5- Shrub- and brushland; 6- Forest; 7- Wetland)
5. Ambient water surface... US 2
UB 1
DS 2
(1- pool; 2- riffle)

6. Bridge structure type 1 (1- single span; 2- multiple span; 3- single arch; 4- multiple arch; 5-cylindrical culvert; 6- box culvert; or 7- other)
7. Bridge length $\mathbf{3 4}$
(feet)
Span length $\underline{\mathbf{3 1}}$
(feet)
Bridge width 26 (feet)

\section{Road approach to bridge:}
8. LB 2 RB 1
( 0 even, 1- lower, 2- higher)
9. LB 1
RB 1
(1- Paved, 2- Not paved)

10. Embankment slope (run / rise in feet / foot)

US left

US right

\begin{tabular}{|c|c|c|c|}
\hline \multicolumn{2}{|c|}{ Protection } & \multirow{2}{*}{ 13.Erosion } & 14.Severity \\
\hline 11.Type & 12.Cond. & - & - \\
\hline $\mathbf{0}$ & - & $\mathbf{0}$ & - \\
$\mathbf{0}$ & - & $\mathbf{0}$ & - \\
\hline $\mathbf{0}$ & - & $\mathbf{0}$ & - \\
\hline $\mathbf{0}$ & - & $\mathbf{2}$ & $\mathbf{0}$ \\
\hline
\end{tabular}

Bank protection types: 0- none; 1- < 12 inches;

2- < 36 inches; 3- < 48 inches;

4- < 60 inches; 5- wall / artificial levee

Bank protection conditions: 1- good; 2- slumped;

3- eroded; 4- failed

Erosion: 0 - none; 1- channel erosion; 2 -

road wash; 3- both; 4- other

Erosion Severity: 0 - none; 1- slight; 2- moderate; 3- severe

\section{Channel approach to bridge (BF):}

15. Angle of approach: $\mathbf{1 0}$

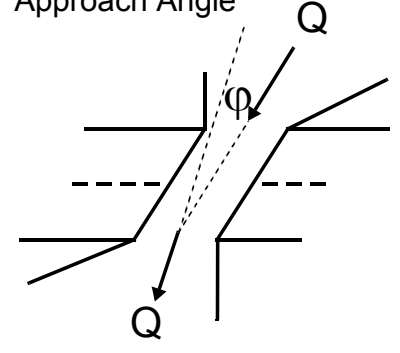

17. Channel impact zone 1 :

Where? LB $(L B, R B)$

Range? 0 feet US

Channel impact zone 2:

Where? RB $(L B, R B)$

Range? $\underline{5}$ feet $\underline{\mathbf{U S}}$

Impact Severity: 0- none to very slight; 1- Slight; 2- Moderate; 3- Severe
16. Bridge skew: 10 Bridge Skew Angle

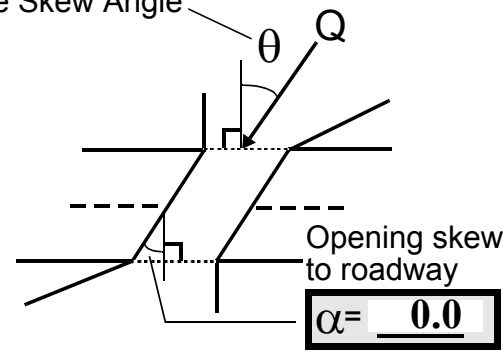

\section{Exist? $\mathbf{Y}(Y$ or $N)$}

Severity $\mathbf{0}$

US, UB, DS) to $\underline{\mathbf{4 0}}$ feet $\underline{\mathbf{U S}}$

Exist? $\mathbf{Y}(Y$ or $N)$

Severity 1

S, UB, DS) to 10 feet $\underline{\mathbf{D S}}$ 
18. Bridge Type: 1a

1a- Vertical abutments with wingwalls

$1 \mathrm{~b}$ - Vertical abutments without wingwalls

2- Vertical abutments and wingwalls, sloping embankment Wingwalls parallel to abut. face

3- Spill through abutments

4- Sloping embankment, vertical wingwalls and abutments

Wingwall angle less than $90^{\circ}$.

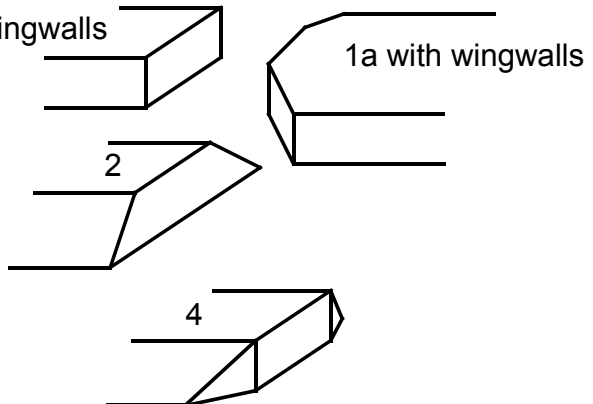

19. Bridge Deck Comments (surface cover variations, measured bridge and span lengths, bridge type variations, approach overflow width, etc.)

Measured bridge length $=34.2 \mathrm{ft}$; measured span length $=31.5 \mathrm{ft}$; measured width $=\mathbf{2 5 . 9} \mathrm{ft}$.

Both the left bank downstream and the right bank upstream have asphalt drainage channels for runoff.

"1925" is cast in the concrete railing on the upstream right bank.

There are guardrails at all four corners.

The U.S. route 4 bridge is $100 \mathrm{ft}$ upstream.

The channel is fairly straight.

There are wood structures on both downstream banks with forest immediately beyond. Upstream (DS of U.S. route 4 bridge) there is a tree-lined bank with mowed grass beyond. Upstream of the Route 4 bridge is forest. The upstream right overbank decreases in elevation from the top of bank following U.S. route 4 to the valley floor.

\section{Upstream Channel Assessment}

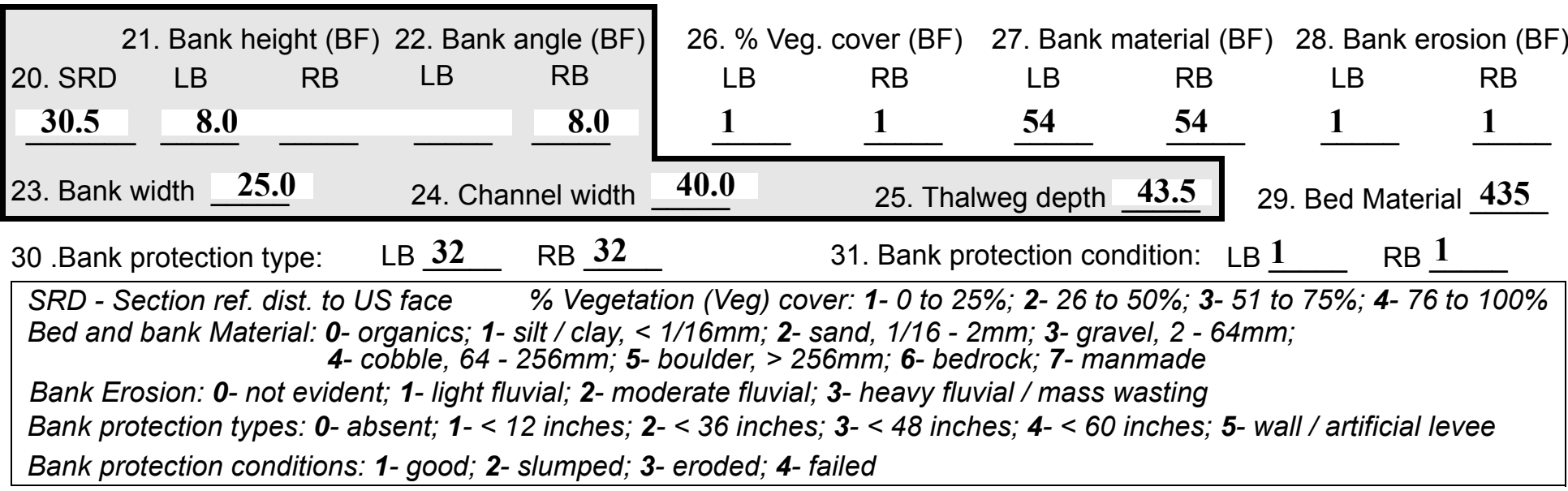

32. Comments (bank material variation, minor inflows, protection extent, etc.):

The protection consists of boulders mostly along the left bank. This is a vertical V-shaped channel. 
33.Point/Side bar present? Y

$(Y$ or $N$. if $N$ type ctrl-n pb)34. Mid-bar distance: $\mathbf{1 0}$

35. Mid-bar width: 12

36. Point bar extent: $\underline{\mathbf{1 5}}$ feet $\underline{\mathbf{U S}}$ (US, UB) to $\underline{\mathbf{1 8}}$ feet $\underline{\mathbf{U B}}$ (US, UB, DS) positioned $\underline{\mathbf{0}} \%$ LB to $\underline{\mathbf{5 0}} \%$ RB

37. Material: 4

38. Point or side bar comments (Circle Point or Sidg; Note additional bars, material variation, status, etc.):

This is a side bar.

39. Is a cut-bank present? $\mathbf{N}$ ( $Y$ or if $N$ type ctrl-n $c b)$

40. Where? - $(L B$ or $R B)$

41. Mid-bank distance: -

42. Cut bank extent: -

feet -

(US, UB) to = feet (US, UB, DS)

43. Bank damage: -

(1- eroded and/or creep; 2- slip failure; 3- block failure)

44. Cut bank comments (eg. additional cut banks, protection condition, etc.):

NO CUT BANKS

45. Is channel scour present? $\mathbf{N}$ ( $Y$ or if $N$ type ctrl-n cs)

47. Scour dimensions: Length -

Width -

Depth : -

46. Mid-scour distance: -

48. Scour comments (eg. additional scour areas, local scouring process, etc.):

NO CHANNEL SCOUR

There is localized scour in the pools between riffles.

49. Are there major confluences? $\mathbf{N}$

51. Confluence 1: Distance -

Confluence 2: Distance -

52. Enters on -

Enters on -

54. Confluence comments (eg. confluence name):

NO MAJOR CONFLUENCES
50. How many? -

53. Type(1- perennial; 2- ephemeral)

Type (1-perennial; 2- ephemeral) ( $L B$ or $R B)$ (LB or $R B)$

\section{Under Bridge Channel Assessment}

55. Channel restraint (BF)? LB 2

\begin{tabular}{|cccc}
\hline \multicolumn{2}{|c}{ 56. Height (BF) } & \multicolumn{2}{c}{57 Angle (BF) } \\
LB & RB & LB & RB \\
$\mathbf{1 9 . 5}$ & & \multicolumn{1}{c|}{$\mathbf{1 . 5}$} & \\
\hline
\end{tabular}

58. Bank width (BF) (1- natural bank; 2- abutment; 3- artificial levee)

Bed and bank Material: 0- organics; 1- silt / clay, < 1/16mm; 2- sand, 1/16 - 2mm; 3- gravel, 2 - 64mm; 4- cobble, 64 - 256mm;

5- boulder, > 256mm; 6- bedrock; 7- manmade

61. Material (BF)

LB $\quad$ RB

$2 \quad-$
62. Erosion (BF)

LB RB

- 2

59. Channel width -

60. Thalweg depth $\lcm{90.0}$

63. Bed Material 2

Bank Erosion: 0- not evident; 1- light fluvial; 2- moderate fluvial; 3- heavy fluvial / mass wasting

64. Comments (bank material variation, minor inflows, protection extent, etc.):

43

Erosion is evident along both abutments.

There is localized scour at the bridge, but it is not greater than in the upstream pools.

There is evidence of channel erosion under the bridge. 
65. Debris and Ice Is there debris accumulation?

67. Debris Potential US (1- Low; 2- Moderate; 3- High)

69. Is there evidence of ice build-up? 1

70. Debris and Ice Comments:

2
(Yor $N)$ 66. Where? $\mathbf{Y}$

68. Capture Efficiency 1

(1- Upstream; 2- At bridge; 3-Both)

Ice Blockage Potential $\underline{\mathbf{N}}$
(1- Low; 2- Moderate; 3- High)

(1-Low; 2- Moderate; 3- High)

\begin{tabular}{|l|c|c|c|c|c|c|c|c|}
\hline Abutments & $\begin{array}{c}\text { 71. Attack } \\
\angle \text { (BF) }\end{array}$ & $\begin{array}{c}72 \text {. Slope } \angle \\
\text { (Qmax) }\end{array}$ & $\begin{array}{c}\text { 73. Toe } \\
\text { loc. (BF) }\end{array}$ & $\begin{array}{c}\text { 74. Scour } \\
\text { Condition }\end{array}$ & $\begin{array}{c}75 . \text { Scour } \\
\text { depth }\end{array}$ & $\begin{array}{c}\text { 76. Exposure } \\
\text { depth }\end{array}$ & 77. Material & 78. Length \\
\hline LABUT & & $\mathbf{0}$ & $\mathbf{9 0}$ & $\mathbf{2}$ & $\mathbf{2}$ & - & $\mathbf{2}$ & $\mathbf{9 0 . 0}$ \\
\hline RABUT & $\mathbf{1}$ & $\mathbf{1 0}$ & $\mathbf{9 0}$ & & & $\mathbf{2}$ & $\mathbf{2}$ & $\mathbf{2 9 . 5}$ \\
\hline
\end{tabular}

Pushed: $L B$ or RB

Toe Location (Loc.): 0- even, 1- set back, 2- protrudes

Scour cond.: 0- not evident; 1- evident (comment); 2- footing exposed; 3-undermined footing; 4- piling exposed; 5- settled; 6- failed

Materials: 1- Concrete; 2- Stone masonry or drywall; 3- steel or metal; 4- wood

79. Abutment comments (eg. undermined penetration, unusual scour processes, debris, etc.):

$4^{*}$

1

74. The left abutment footing is exposed (was undermined but has been repaired- form set and undermining filled in on the upstream and downstream ends). It is penetrable by $0.5 \mathrm{ft}$ just upstream of the center of the abutment.

*A head-cut is occurring under the bridge. The footing exposure on the downstream right bank is $4 \mathrm{ft}$ whereas the footing exposure on the upstream right bank is $2 \mathrm{ft}$.

80. Wingwalls:

$\begin{array}{lllll}\text { Exist? Material? } & \text { Scour } & \text { Scour Exposure } & & \\ \text { Angle? Length? } & \text { Condition? depth? } & \text { depth? }\end{array}$

USLWW:

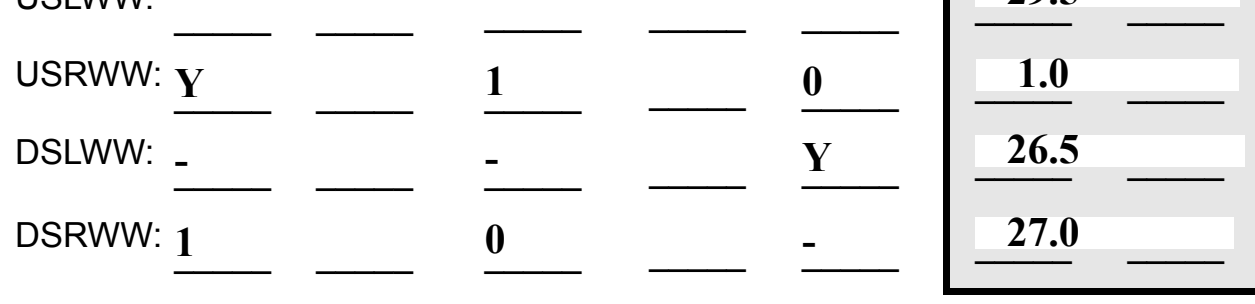

Wingwall materials: 1- Concrete; 2- Stone masonry or drywall; 3- steel or metal; 4- wood

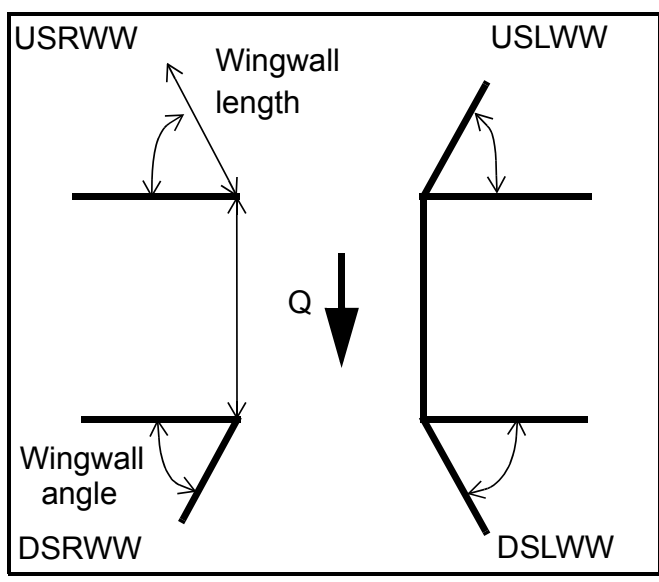

82. Bank / Bridge Protection:

\begin{tabular}{|l|l|l|l|l|l|l|l|l|}
\hline Location & USLWW & USRWW & LABUT & RABUT & LB & RB & DSLWW & DSRWW \\
\hline Type & - & $\mathbf{0}$ & $\mathbf{Y}$ & - & $\mathbf{1}$ & $\mathbf{2}$ & - & - \\
\hline Condition & $\mathbf{Y}$ & - & $\mathbf{1}$ & $\mathbf{4}$ & $\mathbf{1}$ & $\mathbf{1}$ & - & - \\
\hline Extent & $\mathbf{1}$ & - & $\mathbf{3}$ & $\mathbf{3}$ & $\mathbf{3}$ & $\mathbf{0}$ & $\mathbf{0}$ & - \\
\hline
\end{tabular}

Bank / Bridge protection types: 0- absent; 1- < 12 inches; 2- < 36 inches; 3- < 48 inches; 4- < 60 inches; 
83. Wingwall and protection comments (eg. undermined penetration, unusual scour processes, etc.):

-
-
-
-
-
0
-
-
0
-
-

\section{Piers:}

84. Are there piers? Th (Y or if $N$ type ctrl-n pr)

\begin{tabular}{|l|r|r|r|l|l|l|l|}
\hline \multirow{2}{*}{$\begin{array}{l}85 . \\
\text { Pier no. }\end{array}$} & \multicolumn{3}{|c|}{ width (w) feet } & \multicolumn{3}{c|}{ elevation (e) feet } \\
\cline { 2 - 8 } & w1 & w2 & w3 & e@w1 & e@w2 & e@w3 \\
\hline Pier 1 & & & & $\mathbf{4 5 . 0}$ & $\mathbf{1 0 . 0}$ & $\mathbf{4 5 . 0}$ \\
\hline Pier 2 & $\mathbf{9 . 5}$ & $\mathbf{9 . 0}$ & $\mathbf{9 . 5}$ & $\mathbf{9 0 . 0}$ & $\mathbf{9 0 . 0}$ & - \\
\hline Pier 3 & - & - & - & - & - & - \\
\hline Pier 4 & - & - & - & - & - & - \\
-
\end{tabular}

\begin{tabular}{|l|l|l|l|l|}
\hline Level 1 Pier Descr. & \multicolumn{1}{|c|}{1} & \multicolumn{1}{|c|}{2} & \multicolumn{1}{|c|}{3} & \multicolumn{1}{|c|}{4} \\
\hline 86. Location (BF) & ere is a & down- & bank. & erod- \\
\hline 87. Type & built & strea & The & ing \\
\hline 88. Material & up/ & m & bank & and \\
\hline 89. Shape & laid & left & at & mass \\
\hline 90. Inclined? & up & wing & the & wasti \\
\hline 91. Attack $\angle$ (BF) & stone & wall & end & ng \\
\hline 92. Pushed & wall & that & of & has \\
\hline 93. Length (feet) & - & - & - & - \\
\hline 94. \# of piles & at & con- & the & occu \\
\hline 95. Cross-members & the & tinu- & right & rred. \\
\hline 96. Scour Condition & end & ing & abut & 80. \\
\hline 97. Scour depth & of & up & ment & Ther \\
\hline 98. Exposure depth & the & the & is & e \\
\hline
\end{tabular}

LFP, LTB, LB, MCL, MCM, MCR, RB, RTB, RFP

1- Solid pier, 2- column, 3- bent

1-Wood; 2- concrete; 3- metal; 4- stone

1- Round; 2- Square; 3- Pointed

Y-yes; $N-$ no

$L B$ or $R B$

0- none; 1- laterals; 2- diagonals; 3- both

0- not evident; 1- evident (comment);

2- footing exposed; 3- piling exposed;

4- undermined footing; 5- settled; 6- failed 
99. Pier comments (eg. undermined penetration, protection and protection extent, unusual scour processes, etc.):

was undermining beneath the downstream right wingwall with $1 \mathrm{ft}$ penetration with a range pole. The side bar in front of the downstream left wingwall is covered with paved concrete.

$\mathbf{N}$

100.

\section{E. Downstream Channel Assessment}

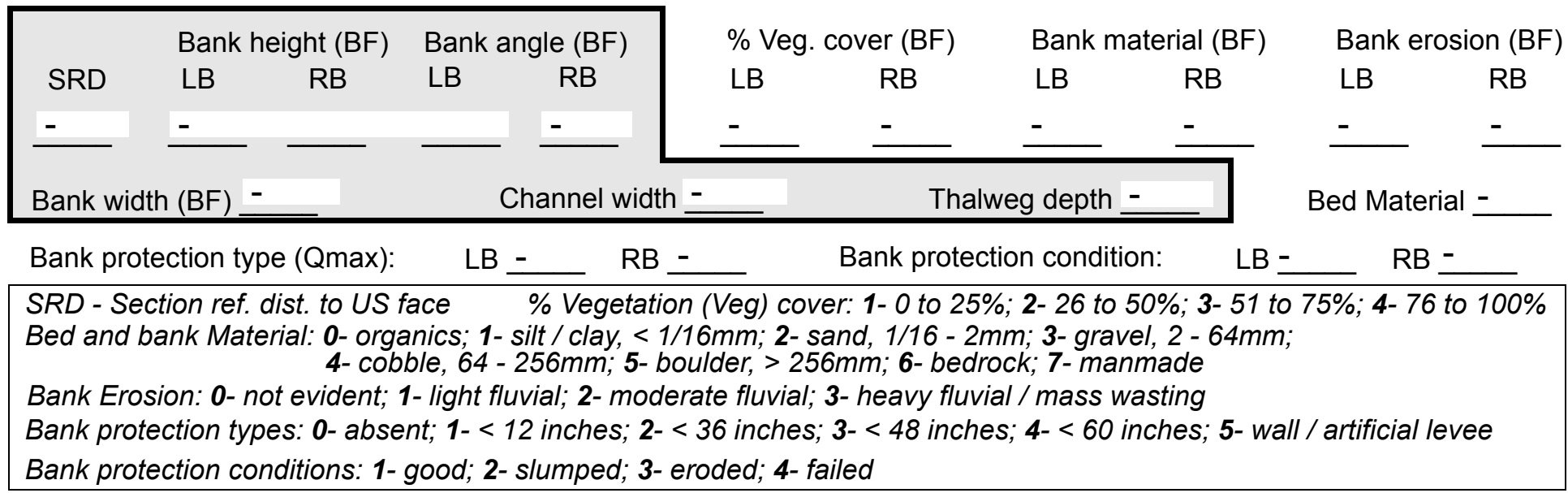

Comments (eg. bank material variation, minor inflows, protection extent, etc.):

$-$

$-$

$-$

-

-

-

-

-

-

-

$-$

-

-

\section{Is a drop structure present? __ ( $Y$ or $N$, if $N$ type ctrl-n $d s) \quad$ 102. Distance: ___ feet}
103. Drop: - feet
104. Structure material:
(1- steel sheet pile; 2- wood pile; 3- concrete; 4- other)

105. Drop structure comments (eg. downstream scour depth):

-

-

-

- 
106. Point/Side bar present? (Y or $N$. if $N$ type ctrl-n pb)Mid-bar distance:

Mid-bar width: -

Point bar extent: feet -

(US, UB, DS) to feet (US, UB, DS) positioned $\%$ LB to $\% \mathrm{RB}$ Material:

Point or side bar comments (Circle Point or Side); note additional bars, material variation, status, etc.):

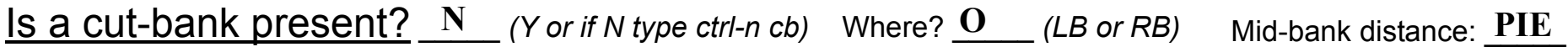
Cut bank extent: $\underline{\mathbf{R S}}$ feet ___ (US, UB, DS) to feet (US, UB, DS)

Bank damage: (1- eroded and/or creep; 2- slip failure; 3- block failure)

Cut bank comments (eg. additional cut banks, protection condition, etc.):

Is channel scour present? Scour dimensions: Length $\underline{4}$ Width 45 ( $Y$ or if $N$ type ctrl-n cs)

Mid-scour distance: $\underline{4}$

Scour comments (eg. additional scour areas, local scouring process, etc.): 453

$-$

Are there major confluences? Confluence 1: Distance bank Confluence 2: Distance natuEnters on $\mathbf{s}$ ( $L B$ or $R B)$ Confluence comments (eg. confluence name): protected to some extent due to large boulders in the bank. There is localized scour occurring in pools downstream of the bridge.

\section{F. Geomorphic Channel Assessment}

107. Stage of reach evolution
1- Constructed

2- Stable

3- Aggraded

4- Degraded

5- Laterally unstable

6- Vertically and laterally unstable 
108. Evolution comments (Channel evolution not considering bridge effects; See HEC-20, Figure 1 for geomorphic descriptors):

$s$ is a vertical $V$-shaped channel. 


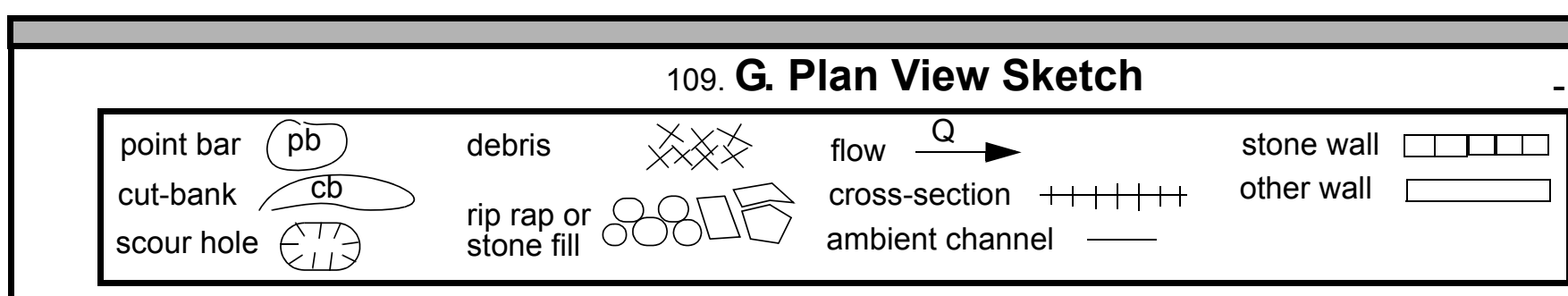


APPENDIX F:

SCOUR COMPUTATIONS 


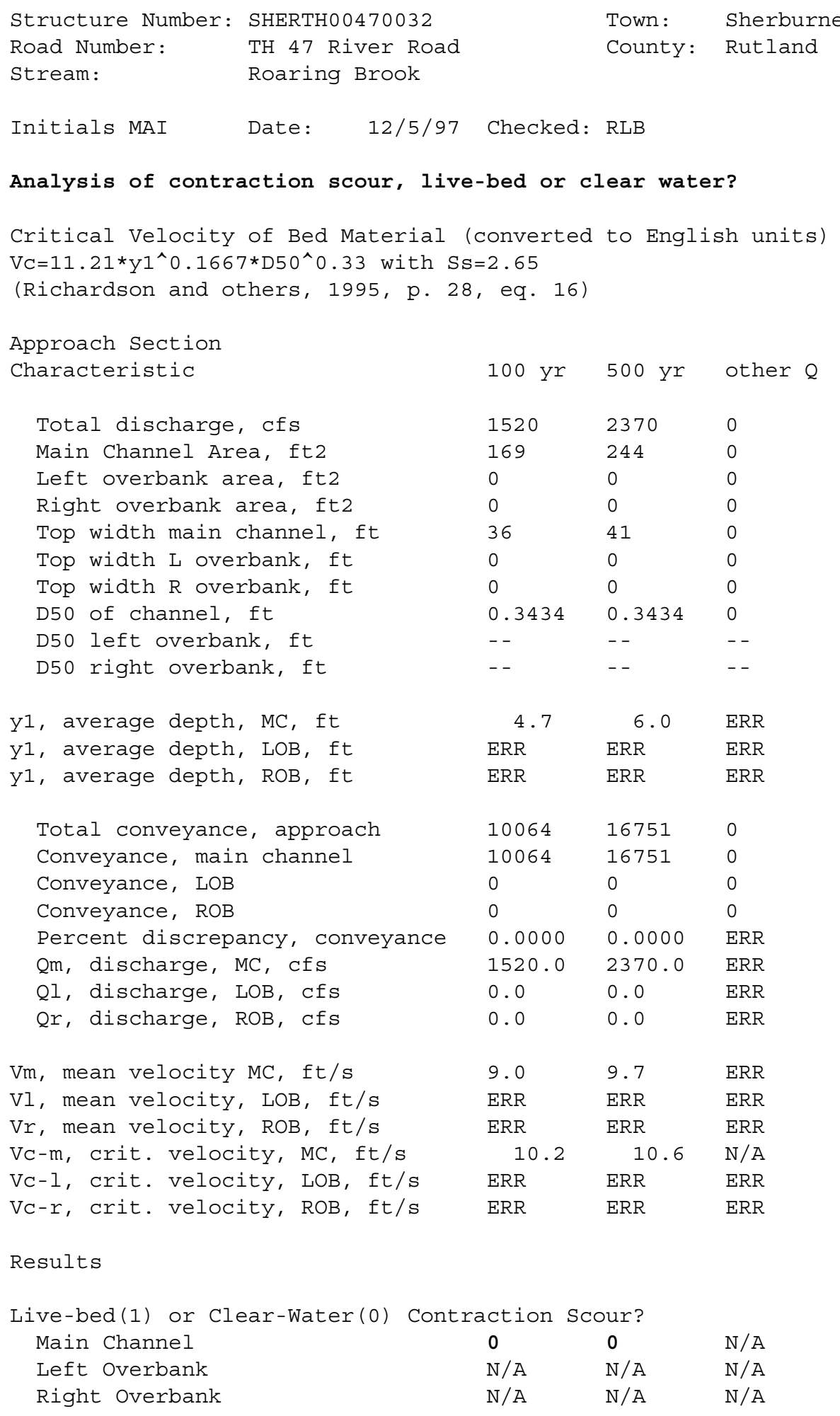




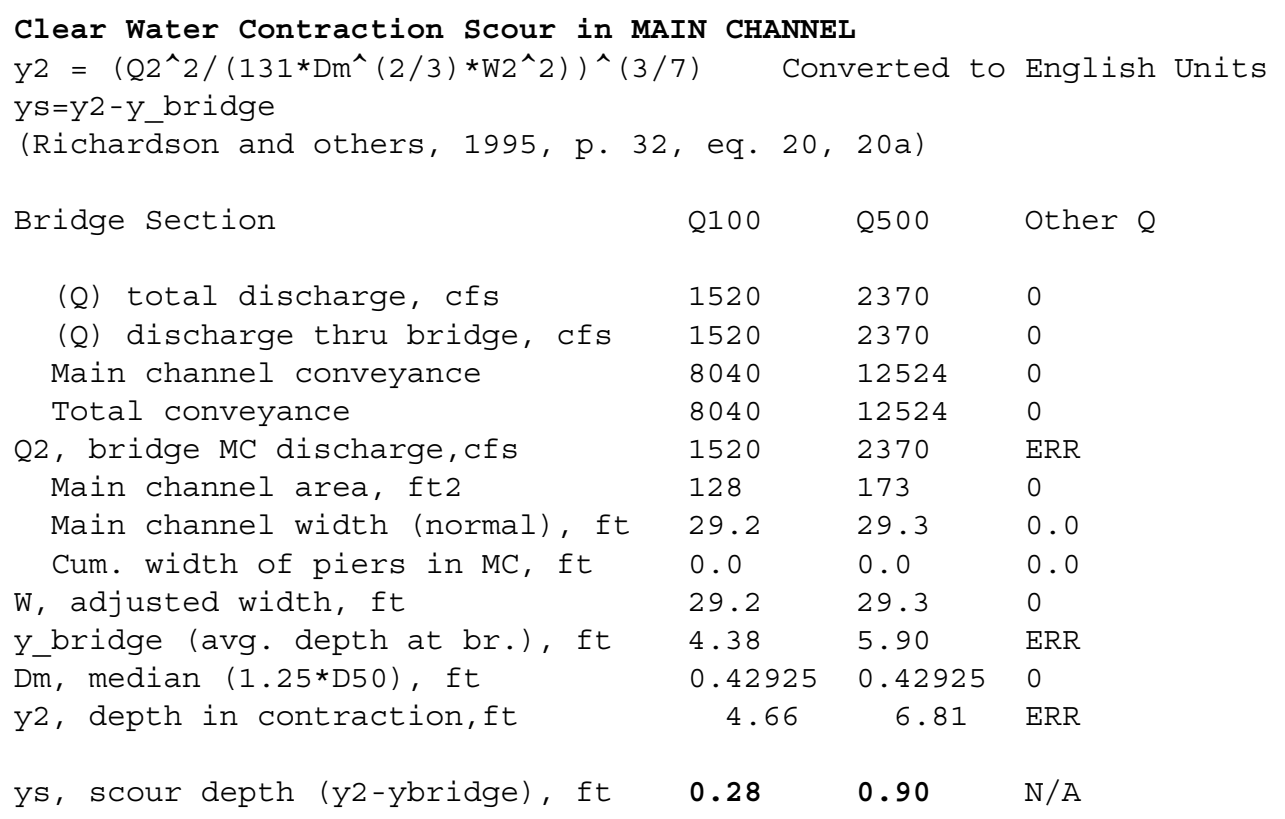

\section{Armoring}

$\mathrm{DC}=\left[\left(1.94 * \mathrm{~V}^{\wedge} 2\right) /(5.75 * \log (12.27 * \mathrm{y} / \mathrm{D} 90))^{\wedge} 2\right] /[0.03 *(165-62.4)]$

Depth to Armoring $=3 *(1 / \mathrm{PC}-1)$

(Federal Highway Administration, 1993)

$\begin{array}{rlll}\text { Downstream bridge face property } & 100-\mathrm{yr} & 500-\mathrm{yr} & \text { Other Q } \\ \text { Q, discharge thru bridge MC, cfs } & 1520 & 2370 & \mathrm{~N} / \mathrm{A} \\ \text { Main channel area (DS), ft2 } & 128 & 173 & 0 \\ \text { Main channel width (normal), ft } & 29.2 & 29.3 & 0.0 \\ \text { Cum. width of piers, ft } & 0.0 & 0.0 & 0.0 \\ \text { Adj. main channel width, ft } & 29.2 & 29.3 & 0.0 \\ \text { D90, ft } & 1.3694 & 1.3694 & 0.0000 \\ \text { D95, ft } & 1.6563 & 1.6563 & 0.0000 \\ \text { DC, critical grain size, ft } & 1.0578 & 1.2044 & \text { ERR } \\ \text { PC, Decimal percent coarser than DC } 0.166 & 0.134 & 0.000\end{array}$

$\begin{array}{llll}\text { Depth to armoring, ft } & 15.94 & 23.35 & \text { ERR }\end{array}$

\section{Abutment Scour}

Froehlich's Abutment Scour

$\mathrm{Ys} / \mathrm{Y} 1=2.27 * \mathrm{~K} 1 * \mathrm{~K} 2 *\left(\mathrm{a}^{\prime} / \mathrm{Y} 1\right)^{\wedge} 0.43 * \mathrm{Fr} 1^{\wedge} 0.61+1$

(Richardson and others, 1995, p. 48, eq. 28)

Characteristic

(Qt), total discharge, cfs
Left Abutment 100 yr Q 500 yr Q Other Q
Right Abutment 100 yr Q 500 yr Q Other Q

$$
\begin{array}{llllll}
1520 & 2370 & 0 & 1520 & 2370 & 0
\end{array}
$$




\begin{tabular}{|c|c|c|c|c|c|c|}
\hline a', abut.length blocking flow, ft & 5.5 & 8.9 & 0 & 0.9 & 2.9 & 0 \\
\hline $\mathrm{Ae}$, area of blocked flow ft 2 & 14.08 & 28.35 & 0 & 2.69 & 10.82 & 0 \\
\hline Qe, discharge blocked abut., cfs & 44.95 & 93.33 & 0 & 10.06 & 41.91 & 0 \\
\hline (If using Qtotal_overbank to obta & in $\mathrm{Ve}$, & eave Qe & blank and & enter $\mathrm{V}$ & e and $\operatorname{Fr} m a$ & anually) \\
\hline Ve, $(\mathrm{Qe} / \mathrm{Ae}), \mathrm{ft} / \mathrm{s}$ & 3.19 & 3.29 & ERR & 3.74 & 3.87 & ERR \\
\hline ya, depth of $\mathrm{f} / \mathrm{p}$ flow, ft & 2.56 & 3.19 & ERR & 2.99 & 3.73 & ERR \\
\hline --Coeff., K1, for abut. type (1.0, & verti.; & $0.82, \mathrm{ve}$ & rti. w/ wi & ingwall; & $0.55, \mathrm{spi}$ & llthru) \\
\hline $\mathrm{K} 1$ & 0.82 & 0.82 & 0.82 & 0.82 & 0.82 & 0.82 \\
\hline --Angle (theta) of embankment $(<90$ & if abut & points & $\mathrm{DS}_{i}>90$ if & $=$ abut. & points US) & \\
\hline theta & 90 & 90 & 90 & 90 & 90 & 90 \\
\hline K2 & 1.00 & 1.00 & 1.00 & 1.00 & 1.00 & 1.00 \\
\hline Fr, froude number $\mathrm{f} / \mathrm{p}$ flow & 0.352 & 0.325 & ERR & 0.381 & 0.353 & ERR \\
\hline ys, scour depth, ft & 6.06 & 7.83 & $\mathrm{~N} / \mathrm{A}$ & 4.83 & 7.04 & $\mathrm{~N} / \mathrm{A}$ \\
\hline \multicolumn{7}{|c|}{$\begin{array}{l}\text { HIRE equation }\left(\mathrm{a}^{\prime} / \mathrm{ya}>25\right) \\
\mathrm{ys}=4 * \mathrm{Fr} \mathrm{r}^{\wedge} 0.33^{*} \mathrm{Y}{ }^{*} \mathrm{~K} / 0.55 \\
\text { (Richardson and others, 1995, p. 49, eq. 29) }\end{array}$} \\
\hline a' (abut length blocked, ft) & 5.5 & 8.9 & 0 & 0.9 & 2.9 & 0 \\
\hline y1 (depth f/p flow, ft) & 2.56 & 3.19 & ERR & 2.99 & 3.73 & ERR \\
\hline$a^{\prime} / y 1$ & 2.15 & 2.79 & ERR & 0.30 & 0.78 & ERR \\
\hline Skew correction (p. 49, fig. 16) & 1.00 & 1.00 & 1.00 & 1.00 & 1.00 & 1.00 \\
\hline Froude no. $\mathrm{f} / \mathrm{p}$ flow & 0.35 & 0.33 & $\mathrm{~N} / \mathrm{A}$ & 0.38 & 0.35 & $\mathrm{~N} / \mathrm{A}$ \\
\hline \multirow{4}{*}{$\begin{array}{l}\text { Ys w/ corr. factor } \mathrm{Kl} / 0.55: \\
\text { vertical } \\
\text { vertical w/ w' }{ }^{\prime} \mathrm{s} \\
\text { spill-through }\end{array}$} & & & & & & \\
\hline & ERR & ERR & ERR & ERR & ERR & $\mathrm{ERR}$ \\
\hline & ERR & ERR & ERR & ERR & ERR & ERR \\
\hline & ERR & ERR & ERR & ERR & ERR & ERR \\
\hline Abutment riprap Sizing & & & & & & \\
\hline \multirow{3}{*}{\multicolumn{7}{|c|}{$\begin{array}{l}\text { Isbash Relationship } \\
\mathrm{D} 50=\mathrm{Y}^{\star} \mathrm{K} * \mathrm{Fr} r^{\wedge} 2 /(\mathrm{Ss}-1) \text { and } \mathrm{D} 50=\mathrm{Y} * \mathrm{~K} *\left(\mathrm{Fr} r^{\wedge} 2\right)^{\wedge} 0.14 /(\mathrm{Ss}-1) \\
\text { (Richardson and others, 1995, p112, eq. 81,82) }\end{array}$}} \\
\hline & & & & & & \\
\hline & & & & & & \\
\hline Characteristic & Q100 & Q500 & Other $Q$ & Q100 & Q500 & Other $\mathrm{Q}$ \\
\hline Fr, Froude Number & 1 & 1 & 0 & 1 & 1 & 0 \\
\hline y, depth of flow in bridge, ft & 4.32 & 5.84 & 0.00 & 4.32 & 5.84 & 0.00 \\
\hline \multicolumn{4}{|c|}{ Median stone Diameter for riprap at: left abutment } & right & = abutment, & ft \\
\hline Fr<=0.8 (vertical abut.) & ERR & ERR & 0.00 & ERR & ERR & 0.00 \\
\hline Fr>0.8 (vertical abut.) & 1.81 & 2.44 & ERR & 1.81 & 2.44 & ERR \\
\hline
\end{tabular}


